\title{
Nāgārjunian-Yogācārian Modal Logic versus Aristotelian Modal Logic
}

\author{
Andrew Schumann ${ }^{1}$ (D)
}

Accepted: 7 April 2021/Published online: 26 May 2021

(C) The Author(s) 2021

\begin{abstract}
There are two different modal logics: the logic $\mathbf{T}$ assuming contingency and the logic $\mathbf{K}=$ assuming logical determinism. In the paper, I show that the Aristotelian

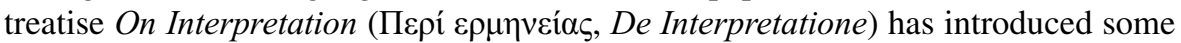
modal-logical relationships which correspond to $\mathbf{T}$. In this logic, it is supposed that there are contingent events. The Nāgārjunian treatise İ́vara-kartṛtva-nirākrtih-viṣnoh-ekakartrtva-nirākaraṇa has introduced some modal-logical relationships which correspond to $\mathbf{K}=$. In this logic, it is supposed that there is a logical determinism: each event happens necessarily (siddha) or it does not happen necessarily (asiddha). The Nāgārjunian approach was inherited by the Yogācārins who developed, first, the doctrine of causality of all real entities (arthakriyātva) and, second, the doctrine of momentariness of all real entities (kșanikavāda). Both doctrines were a philosophical ground of the Yogācārins for the logical determinism. Hence, Aristotle implicitly used the logic $\mathbf{T}$ in his modal reasoning. The Madhyamaka and Yogācāra schools implicitly used the logic $\mathbf{K}=$ in their modal reasoning.
\end{abstract}

Keywords Aristotle $\cdot$ Stoics · Chrysippus · logic · modal logic · Nāgārjuna Madhyamaka $\cdot$ Yogācāra $\cdot$ nyāya

\section{Introduction}

Conventionally, Aristotle has been considered the father of modal logic. So, his treatise

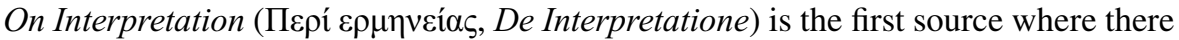
are found well-defined logical relationships among different modal propositions, such

Andrew Schumann

andrew.schumann@gmail.com

1 Department of Cognitive Science and Mathematical Modelling, University of Information Technology and Management in Rzeszow, Sucharskiego 2, 35-225 Rzezsow, Poland 
as "it is possible that $A$ " (symbolically from the point of view of modern modal logic: $\checkmark A$ ) or "it is necessary that $A$ " (symbolically: $\square A$ ). Recently, these relationships are formalized by the mathematicians within modal logic $\mathbf{D}$ and its extension $\mathbf{T}$, see (Garson 2006). Hence, we can state that Aristotle knew modal logic in the version of T, indeed (see "Some General Remarks on Modal Logic", 5). He was first who understood it well and was able to describe its main properties, but without its formalization and axiomatization made just recently. It can be readily shown by many quotations from the Aristotelian text (see "Some General Remarks on Modal Logic", 5).

There was also a Stoic version of modal logic, but it has remained not formalized yet, because there are a few Stoic fragments on modal reasoning to be formalized unequivocally. Nevertheless, we see that their modal logic was non-Aristotelian surely and it can be treated within the modal logic $\mathbf{C D}$ and its extension $\mathbf{K}=$, see (Garson 2006) - as I show in this paper (see "Some General Remarks on Translations of Logical Terms", 6).

The difference is that in $\mathbf{T}$ the statement "If it is necessary that $A$, then $A$ " ( $\square A \Rightarrow$ $A$ ) is one of the main axioms, while in $\mathbf{K}=$ an appropriate converse "If $A$, then it is necessary that $A$ " $(A \Rightarrow \square A)$ is a key axiom. The first statement assumes that there is a contingency - something that appears occasionally. The second statement supposes a logical determinism - if something exists, it exists necessarily. Aristotle follows the first modal axiom, while the Stoics share the second one ("Logical Determinism and hetut $\bar{a}$ " section).

In this paper, I show that the early Madhyamaka and Yogācāra support a kind of logical determinism, too, therefore their reasoning can be formalized within the modal $\operatorname{logic} \mathbf{K}=$, as well (see "Logical Determinism and hetutā" section). So, it can be done in the way of Stoics and versus the Aristotelian intuition on modal logic.

Traditionally, Nyāya and Mīmāṃsā, the Indian logic and hermeneutics, have been considered a tradition beyond any modal logic, because we do not have clear direct Sanskrit analogies with expressions "it is possible that $A$ " or "it is necessary that $A$ " in the meaning of $\mathbf{T}$ or $\mathbf{K}=$. However, as I show in this paper, there are many texts of early Madhyamaka and Yogācāra with clear modal reasoning, but not in the way of Aristotle (i.e. not in the way of logic $\mathbf{T}$, but within the logic $\mathbf{K}=$ ). For instance, this reasoning is well presented in the Nāgārjuna's Íśvara-kartṛtvanirākrtihh-viṣnoh-ekakartrtva-nirākaraṇa (its text and translation are contained in (Stcherbatsky 1969)). This short treatise is to propose a kind of critics of monotheism (the concept of Ísvara) by appealing to some modal relationships which can be formalized even mathematically within $\mathbf{K}=$ (see "Nāgārjuna's Intuition towards Modal Logic" section). Later these critics became traditional for Madhyamaka and Yogācāra and there are many other texts on the same subject that can be symbolically reconstructed within the modal logic $\mathbf{K}=$. This logic is of interest because there are some logical and terminological similarities to Stoic modal reasoning. For example, the Nāgārjuna's term siddha can be understood as a Stoic "to be resulted", "to be fated" or "to be necessitated".

In the İ́vara-kartṛtva-nirākrtiḥ-viṣnoh-ekakartṛtva-nirākaraṇa, Nāgārjuna's examples for the modality "it is impossible that it is $A$ " (or "it is necessary that it is not $A$ ": "oil [crushed] out of sand, which is known to us as nonexistent; wool on a 
tortoise, which is known to us as non-existent" (Stcherbatsky 1969), p. 9. Using these examples Nāgārjuna shows that if the Creator (Íśvara) exists, He creates something from nothing, such as "wool on a tortoise". It means that He can make "possible" from "impossible". The assumption that "possibility" and "impossibility" exist simultaneously gives a contradiction in $\mathbf{K}=$ and then it should be rejected. As a consequence, the Creator does not exist, too. The assumption of His existence should be rejected, also, as entailing a contradiction between the modalities "possible" and "impossible".

This short Nāgārjuna's argumentation is absolutely correct from the point of view of logic $\mathbf{K}=$. All existent items are necessary (siddha): "If $A$, then it is necessary that $A$ ". Among non-existent items there are items $B$ which are possible: "it is possible that $B$ ". From the statement "If $A$, then it is necessary that $A$ " it follows logically that "If it is possible that it is not $A$, then non- $A$ ". These possible items cannot be created, because the conjunction "it is possible that non- $A$ and it is necessary that $A$ " is always false in $\mathbf{K}=$. Thus, we can claim that Nāgārjuna knew some relationships of modal logic $\mathbf{K}=$, but without its formalization and axiomatization made just recently.

He became the father of Indian rational thinking, indeed. Usually, in the secondary Western literature Nāgārjuna is interpreted as a skeptic philosopher who avoids logic. But he does it only for an especial philosophical topic, not in general. He always starts with logical reasoning. This misunderstanding causes some mistakes in his translations. Nāgārjuna has stood at the gates of the beginning of logical discourse in India, while Aristotle has been at the forefront of the same in Greece. For instance, in a categorical proposition ' $S$ is $P$ ', Aristotle was one of the first in Greece who has defined and used

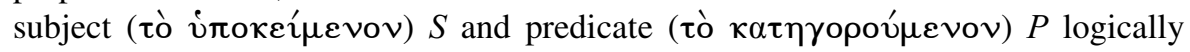
correctly as well as Nāgārjuna was one of the first in India who has defined and used subject (dharmin) $S$ and predicate (dharma) $P$ perfectly from the point of view of logic to the same extent: (i) the subject $S$ of categorical proposition ' $S$ is $P$ ' should be expressed by a non-empty name (for some $A, A$ is $S$ ); (ii) the subject $S$ of categorical proposition ' $S$ is $P$ ' should be a subset of $P$ (for any $A$, if $A$ is $S$, then $A$ is $P$ ). Both properties may be shown by Venn diagrams:

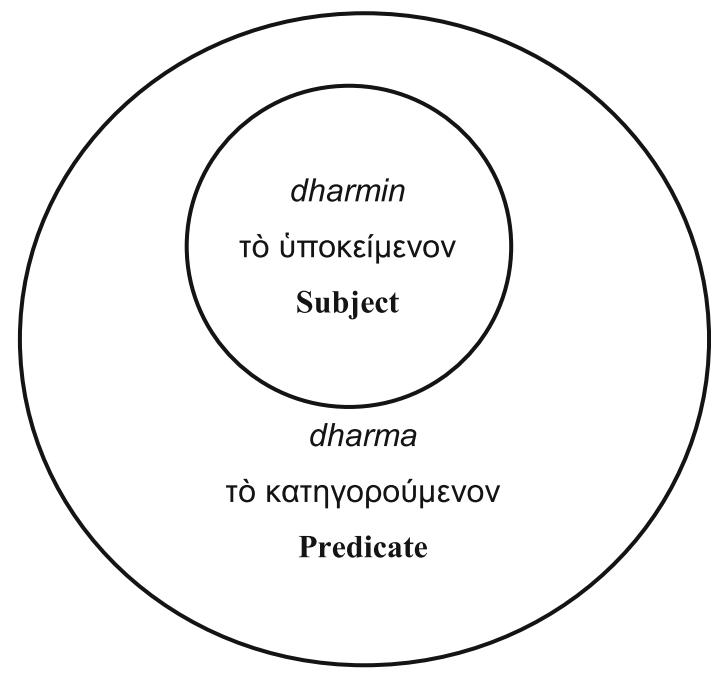


Nāgārjuna possessed a perfect logical competence and his treatises should be translated with explicating his logical knowledge, too. For example, the Mülamadhyamakakārika contains many categorical statements in the form ' $S$ is P', see (Tachikawa 1981), p.11. So, the statement from this treatise (Mūlamadhyamakakārikā 7, 20), see (Mūlamadhyamakakārikās 1903):

sataś ca tāvad utpattir asataś ca na yujyate |

na sataś cāsataś ceti .... ॥

was understood by Musashi Tachikawa as a conjunction of the following three categorical propositions: (i) sato notpattih ['There is no arising of that which exists'; sat (that which exists) is not utpatti (arising); it is false that if sat, then utpatti]; (ii) asato notpattih ['There is no arising of that which does not exist'; asat (that which does not exist) is not utpatti (arising); it is false that if asat, then utpatti]; (iii) sadasato notpattih ['There is no arising of that which both exists and does not exist'; sadasat (that which both exists and does not exist) is not utpatti (arising); it is false that if sadasat, then utpatti]. In this passage, Nāgārjuna claims that utpatti is not a property of sat, it is not a property of asat, and it is not a property of sadasat. Hence, utpatti cannot be inferred from sat, asat, and sadasat. If we understand utpatti of $A$ modal-logically as "it is possible that $A$ ", sat of $A$ as " $A$ " and asat of $A$ as "not $A$ ", then Nāgārjuna's reasoning is formalized as follows:

$$
\begin{array}{ll}
\neg(A \Rightarrow \diamond A) & \text { It is false that if } A, \text { then it is possible that } A \\
\neg(\neg A \Rightarrow \diamond A) & \text { It is false that if not } A \text {, then it is possible that } A
\end{array}
$$

Proposition (1) is always false in the modal logic $\mathbf{T}$, because $A \Rightarrow \diamond A$ is an axiom of that logic, but (1) can be true in the modal logic $\mathbf{K}=$. Statement (2) can be true in $\mathbf{K}=$, also. Thus, we see that Nāgārjuna has a non-Aristotelian intuition on modal relationships. In $\mathbf{K}=$, from (1) we can logically infer (3) and from (2) we can infer (4):

$$
\begin{aligned}
& A \wedge \square \neg A \\
& \neg A \wedge \square \neg A
\end{aligned}
$$

$A$ and it is necessary that not $A$

Not $A$ and it is necessary that not $A$

Hence, the aim of this paper does not concern the Buddhist doctrine taught by Nāgārjuna or other representatives of Madhyamaka and Yogācāra, but the aim is to reconstruct some formal-logical schemata, more or less implicitly or even explicitly applied in the early philosophical discourse of Madhyamaka and Yogācāra, to show that they have an intuition towards a modal logic with strict relationships among modal propositions. A theoretical level of philosophical discourse depends upon logical schemata involved in reasoning. We know that the theoretical level of postAristotelian Old-Greek philosophers was really high. There are many modern formalizations of Aristotelian and Stoic logical schemata to emphasize the abstract level of these Ancient philosophers. However, we consider the first Indian philosophers such as Nāgārjuna as mystic authors still and we ignore the fact that 
many of them possessed a perfect logical competence and they were able to engage very difficult logical schemata correctly indeed. In this paper I am going to show that since Nāgārjuna in the early philosophical discourse of Madhyamaka and Yogācāra, there was a well-expressed intuition on the modal logic $\mathbf{K}=$. This proves the claim that the first Indian philosophers (of the second century A.D. - the time of Nāgārjuna if to follow the early Chinese Buddhist chronics, see (Beal, Samuel. SiYu-Ki. Buddhist Records of the Western World. In two volumes. Vol. I. London Kegan: Paul, Trench, Trübner \& co 1884), pp. 302-303) had a theoretical level that was not worse than the level of post-Aristotelian Ancient philosophers. The difference in respect to modal reasoning was that in India the modal logic $\mathbf{K}=$ was preferable in thinking, but in Greece the modal logic $\mathbf{T}$.

\section{Madhyamaka and Logic}

There were some recent attempts of analyzing the Nāgārjunian logical discourse worth mentioning: (i) explicating his logical schema called catuṣkoți (enumerating four alternatives: 'something holds, it doesn't hold, it both holds and fails to hold, it neither holds nor fails to hold') (Westerhoff 2005); (ii) explicating his argument 'neither one nor many' (Tillemans 1984); (iii) reconstructing his semantic views including his approach to the problem of empty names and the relation between language and momentariness (Kantor and Salvini 2019; Westerhoff 2019). These discoveries show that logical reasoning played a significant role in the Nāgārjunian philosophy in fact.

Let us quote the following statement from Mūlamadhyamakakārikī 24, 10 (see (Mūlamadhyamakakārikās 1903)) showing that according to Nāgārjuna, logic is, indeed, absolutely necessary for understanding the Buddhist doctrine:

vyavahāram anāśritya paramārtho na deśyate I

paramārtham anāgamya nirvāṇam nādhigamyate ॥

Without relying on words [vyavahāra], the ultimate [paramārtha] is not taught. Without comprehending the ultimate [paramārtha], nirvāna is not attained.

The same verse in Tibetan, see (Ui et al. 1934), N 3824:

tha snyad la ni ma brten parll

dam pa'i don ni bstan mi nus ॥

dam pa'i don ni ma rtogs par $\|$

mya ngan 'das pa thob mi 'gyur $\|$

In the commentary on the Mülamadhyamakakārikā entitled the Prasannapadā (Mūlamadhyamakakārikās 1903) and written in the 7th century by the Buddhist master Candrakīrti, the term 'words [vyavahära]' is treated as the 'level of conventional reality [samvriti-satya]': 
tasmān nirvānāadhigamopāyatvād avaśyam eva yathāvasthitā samivrtir ādāv evābhyupeyā bhājanam iva salilārthineti $\|10\|$

So, if it is the means (upāya) to attain nirvāna, then the conventional [samvrrti] should be necessarily used from the beginning, as it happens to be; just like a container is used by someone who wants water (Prasannapadā 24, 10).

It is worth noting that this phrase of Candrakīrti is composed as a logical reasoning supported by upamā (metaphor): 'like a container is used by someone who wants water' - this upamā is a necessary step in inferring, according to the Yogācāra and Nyāya logic (Vattanky 2003).

Hence, by this commentary, Candrakīrti postulates following Nāgārjuna that in order to reach the 'level of ultimate reality [paramārtha-satya]' we should go first through the 'level of conventional reality [samvrti-satya]'. At the end, the paramärtha-satya shall be revealed as the emptiness of all phenomena - as the śünyatā of vyavahāra or samvrti (Sebastian 2016), p. 62. But in the beginning, we should investigate all the phenomena trough logic - that is, through a 'valid cognition of empirical reality [vyāvahārika-pramāna]', because this cognition is "a cause of the correct cognition of the paramārtha" (Seyfort Ruegg 2000), p.280. The idea that the 'level of conventional reality [samvrti-satya]' concerns only words and their correct usage is well expressed by Buddhapālita, another early commentator on the Nāgārjunian Mūlamadhayamakakārikā, please see his upamā (metaphor):

As two villagers were passing through a city on business, they entered a temple to take in the sights. As they began examining the paintings, one remarked, "The one holding the trident is Narāyāna; the one with the discus is Maheśvara." The other answered, "You have it wrong. Maheśvara holds the trident and Narāyāna has the discus." As they argued, they came upon a nearby wandering sage. They paid their res pects and each explained his opinion. To one of them the sage replied, "What you say is true," and to the other he said, "What you say is not true." (Cowherds 2011), p. 7.

This metaphor was to demonstrate that, according to the conventions (vyavahāra), Maheśvara holds the trident and Narāyāna holds the discus, but not vice versa, although they do not exist as such to the same extent. Therefore something is either true or false only due to some conventions sharing by us and logic is the best way for checking our correctness. Thus, the Nāgārjunian treatise Íśvara-kartṛtvanirākrtih̆-viṣnoh-ekakartrtva-nirākaraṇa (Stcherbatsky 1969) is devoted to the 'level of conventional reality [samvriti-satya]' and how we can consider our conventions in respect to gods due to logic as well as how we can show that some conventions about gods are wrong in fact, since they contradict to themselves. As we see, the Íśvara-kartrtva-nirākrtih-viṣnoh-ekakartrtva-nirākaraṇa is well placed in a cultural and philosophical context of the early Madhyamaka and Yogācāra texts, indeed; therefore it can be dated to the $2^{\text {nd }}-4^{\text {th }}$ centuries A.D.

The founder of the Gelug school of Tibetan Buddhism, Je Tsongkhapa (13571419), followed the Nāgārjunian-Candrakīrtian treatment of differences between samvrti-satya and paramārtha-satya and the believe that the samvrti-satya is a 
prolegomena to the paramärtha-satya. As a reslt, it is no wonder that he organized the monastery education in the following manner: logic is taught first and only then the Madhyamaka philosophy. So, in the Gelug tradition, the Buddhist doctrine is taught at the following five successive levels:

1. The first subject (course) of monastery education is called 'valid cognition (logic)' (tshad ma). The main text (gzhung) of this course is written by the Yogācāra philosopher Dharmakīrti (chos kyi grags pa, c. $6^{\text {th }}$ or $7^{\text {th }}$ century), it is entitled the Commentary on Valid Cognition (Pramānavārttika, tshad ma rnam 'grel) (Ui et al. 1934), N 3713. As a consequence, the Buddhist education in Gelug is started with studying the logic of Yogācāra.

2. The second subject (course) is called 'perfection of understanding' (phar phyin). Its main text (gzhung) is presented by the Treatise Containing the Commentary to [the Sütra of] Perfection of Understanding, Called the 'Ornament of Clear Realization' (Abhisamayālamkāra, shes rab kyi pha rol tu phyin pa'i man ngag gi bstan bcos mngon par rtogs pa'i rgyan ces nya ba) (Ui et al. 1934), N 3786. The authorship of this book is ascribed to Maitreya (byams pa).

3. The third subject (course) is called 'middle way' (madhyamaka, dbu ma). The Introduction to Madhyamaka (Prasannapadā, dbu ma la ‘jug pa) by Candrakīrti (zla ba grags pa) (Ui et al. 1934), N 3861, is its main text (gzhung).

4. The fourth subject (course) is called 'knowledge about dharma' (abhidharma, chos mngon). The Treasury of Abhidharma (Abhidharmakośa, chos mngon pa'i mdzod) authored by Vasubandhu (dbyig gnyen, c. $4^{\text {th }}$ or $5^{\text {th }}$ century) (Ui

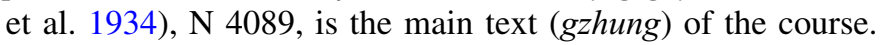

5. The last, fifth subject (course) is called 'monastic discipline', its main text (gzhung) is presented by the Sütras on Monastic Disciplines ('dul ba'i mtha' dpyod) (Ui et al. 1934), N 4117.

The Yogācāra logic has been examined as a foundation of Buddhist knowledge in the Gelug school until now. Representatives of this school have written many books on the 'valid cognition' (logic) since Je Tsongkhapa who wrote his well-known Introduction to the Seven Treatises of the Hetuvidyā by Dharmakirti (sde bdun la 'jug pa'i sgo don gnyer yid kyi mun sel) (Descriptive Catalogue of the Naritnsan Institute Collection of Tibetan Works 1989), p. 213, N 1589. In the Gelug monastery education as well as in the education of other schools of Tibetan Buddhism, the learning process has two dimensions assuming a perfect logical knowledge: (i) studying some written commentaries (yig cha) and oral commentaries (khrid) composed as a set of logical reasoning; (ii) participating in debates on the subject of these commentaries (rtags gsal, rtsod pa). In the debates, argumentation is formed either as a Yogācāra syllogism (sbyor ba) or as reductio ad absurdum (thal 'gyur).

To sum up, in Gelug as in a living tradition of Madhyamaka, the logical discourse is a necessary step for comprehending the ultimate (paramārtha). In my paper, I assume that modern symbolic logic can be applied as a reliable tool for the valid cognition at the level of conventional reality (samvrti-satya) and for the explicating 
our conventions about gods in the way of how Nāgārjuna did it in his Ísvarakartṛtva-nirākṛtiḥ-viṣnoh-ekakartṛtva-nirākaraṇa (Stcherbatsky 1969).

\section{Some General Remarks on Modal Logic}

Philosophers of language since John Langshaw Austin (1911-1960) and John Rogers Searle (born 1932) have distinguished performative propositions designating and expressing our behavior from informative propositions denoting facts. While informative propositions describe states of affairs (objective reality), performative propositions express our emotional and cognitive valuations in respect to states of affairs to commit common interactions. So, meanings of informative propositions do not depend upon us, but meanings of performative propositions depend on contexts of our interactions with other people. For example, the proposition "this apple is red" is informative, while the proposition "I insist that I am right" is performative.

Our evaluations in performative propositions are made by using performative verbs: 'think', 'like', 'order', 'ask', etc. These verbs express a kind of modality. In the meanwhile, they can show a weaker or stronger aspect of the same modality. For instance, 'asking' is weaker, than 'ordering', and 'ordering' is stronger, than 'asking', although they demonstrate the same modality expressing to do something for us. Another example is that 'assuming' is weaker, than 'believing', and 'believing' is stronger, than 'assuming', although they express the same modality of our subjective acceptance for something. Hence, for each performative verb we can find its couple which appeals to the same modality, but in a weaker or stronger form.

Among different performative verbs, there are the following two: 'be necessarily' and 'be possibly'. They express the same modality showing that something is caused, but 'be necessarily' is stronger and at the same time 'be possibly' is weaker.

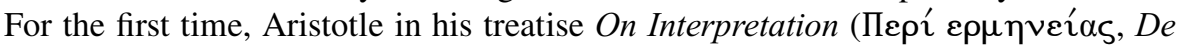
Interpretatione) paid attention that we can construct a kind of symbolic logic for all relationships among propositions with these two forms of the same modality expressing that something is caused.

In his logic he defined the following basic propositions (see "Aristotelian Modal Logic" section):

- $A$, any informative proposition;

- $\square A$, to read: " $A$ is necessarily";

- $\diamond A$, to read: " $A$ is possibly";

- $\square \neg A$, to read: "Not $A$ is necessarily";

- $\diamond \neg A$, to read: "Not $A$ is possibly".

All other propositions are obtained as their logical compositions. Aristotle demonstrated some logical relationships among these basic propositions and these relationships were presented by Scholastic and Modern philosophers graphically as the following three squares of oppositions (see "Aristotelian Modal Logic" section): 
Square 1 .

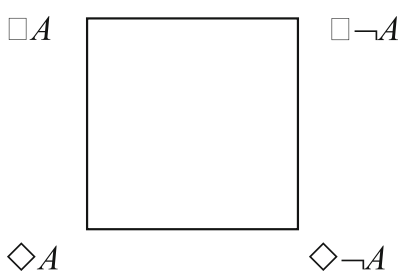

In this square, $\square A$ and $\diamond \neg A$ are contradictories, $\square \neg A$ and $\diamond A$ are contradictories, $\square A$ and $\square \neg A$ are contraries, $\diamond A$ and $\diamond \neg A$ are subcontraries, $\diamond A$ is a subaltern of $\square A, \diamond \neg A$ is a subaltern of $\square \neg A$.

Square 2 .

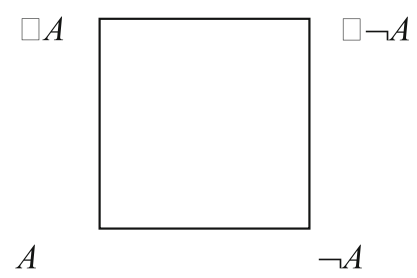

In this square, $\square A$ and $\neg A$ are contraries, $\square \neg A$ and $A$ are contraries, $\square A$ and $\square \neg A$ are contraries, $A$ and $\neg A$ are contradictories, $A$ is a subaltern of $\square A, \neg A$ is a subaltern of $\square \neg A$.

\section{Square 3.}

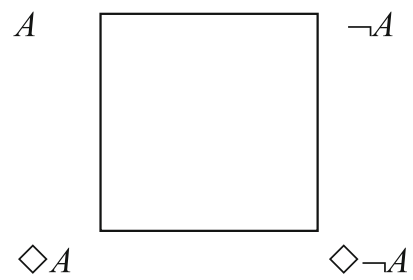

In this square, $A$ and $\diamond \neg A$ are subcontraries, $\neg A$ and $\diamond A$ are subcontraries, $A$ and $\neg A$ are contradictories, $\diamond A$ and $\diamond \neg A$ are subcontraries, $\diamond A$ is a subaltern of $A$, $\diamond \neg A$ is a subaltern of $\neg A$.

Let us remember that two propositions are contradictory if and only if they cannot both be true and they cannot both be false. Two propositions are contraries if and only if they cannot both be true but can both be false. Two propositions are subcontraries if and only if they cannot both be false but can both be true. A proposition is a subaltern of another if and only if it must be true if its superaltern is true, and the superaltern must be false if the subaltern is false.

Squares 1, 2, and 3 satisfy the modal logic T (see "Aristotelian Modal Logic" section). Aristotle considered two modal (performative) verbs: 'be necessarily' and 
'be possibly', but the modal logic introduced by him describes all the relationships for all couples of stronger and weaker performances with the same modality. For example, let $\square A$ mean "I insist to do $A$ ", $\diamond A$ mean "I ask to do $A$ ", $\square \neg A$ mean "I insist not to do $A$ ", $\diamond \neg A$ mean "I ask not to do $A$ ". Then Squares 1, 2, and 3 hold true, as well.

Hence, the basic modal logic (such as $\mathbf{T}$ ) is not a study of necessity and possibility as such, but it is a study of weaker and stronger performances with the same modality. Therefore if we are going to discover a modal-logical reasoning in ancient Indian philosophy, we do not have to find words 'possible' and 'necessary', because the Indian modal logic can be founded on other performative verbs. For example, the term utpatti ('arising') from the Nāgārjunian treatise Mūlamadhyamakakārikā is studied in its logical relations to the terms sat ('being') and asat ('not being'). This utpatti expresses a weak performance within the modality showing that something is caused, while sat and asat express a neutral performance of the same modality. Therefore we can understand utpatti as $\diamond A$, sat as $A$, asat as $\neg A$. Then we can check whether the Nāgārjunian reasoning satisfies a modal logic.

\section{Some General Remarks on Translations of Logical Terms}

The main modal-logical intuition of Aristotle is summarized by Squares 1, 2, and 3. It is based on the idea that any weak performance follows from an appropriate strong performance of the same modality. For example, "I ask you" follows from "I order you" or "It is possible" follows from "It is necessary".

In the Nāgārjunian treatise Íśvara-kartrtva-nirākṛtih-viṣnoh-ekakartṛtva-nirākarana (Stcherbatsky 1969), we find the following two performative terms: siddha and its negation asiddha. The literal meaning of siddha has two aspects: (i) something ontic expressing that it is resulted (produced or established) and (2) something epistemic expressing that it is proved (i.e. resulted also, but epistemicly). So, this word shows a strong performance for the modality demonstrating causal relations. It is worth noting that in the Sroic logic, performative words for expressing a strong performance of the same modality have the close literal meaning 'be resulted'. So, even in Greek philosophy different thinkers used different performative verbs to denote the modal operator $\square$.

Something existent is a neutral form of this modality. According to Aristotle (see Square 2), it means that something existent $(A)$ follows from the strong performance $(\square A)$. Nevertheless, it is wrong from the Nāgārjunian point of view. For him, the strong performance or siddha $(\square A)$ follows from something existent or sat $(A)$. Thus, instead of Square 2 we can reconstruct the following square in his treatise (see "Nāgārjuna's Intuition towards Modal Logic" section): 
Nāgārjunian Square.
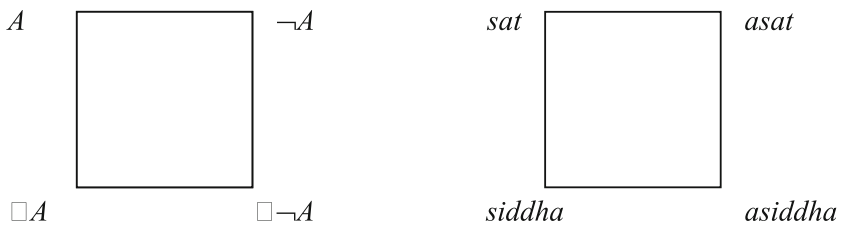

In this square, $\square A$ and $\neg A$ are subcontraries, $\square \neg A$ and $A$ are subcontraries, $\square A$ and $\square \neg A$ are subcontraries, $A$ and $\neg A$ are contradictories, $\square A$ is a subaltern of $A, \square \neg A$ is a subaltern of $\neg A$.

In the Stoic fragments, we can reconstruct the following squares (see "Logical Determinism and hetut $\vec{a}$ " section):

Square 4.

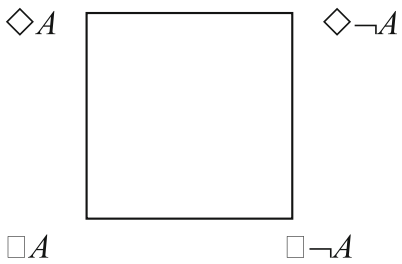

In this square, $\square A$ and $\diamond \neg A$ are contradictories, $\square \neg A$ and $\diamond A$ are contradictories, $\square A$ and $\square \neg A$ are subcontraries, $\diamond A$ and $\diamond \neg A$ are contraries, $\square A$ is a subaltern of $\diamond A, \square \neg A$ is a subaltern of $\diamond \neg A$.

\section{Square 5.}

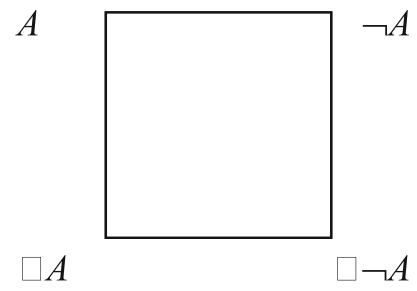

In this square, $\square A$ and $\neg A$ are subcontraries, $\square \neg A$ and $A$ are subcontraries, $\square A$ and $\square \neg A$ are subcontraries, $A$ and $\neg A$ are contradictories, $\square A$ is a subaltern of $A, \square \neg A$ is a subaltern of $\neg A$. 
Square 6.

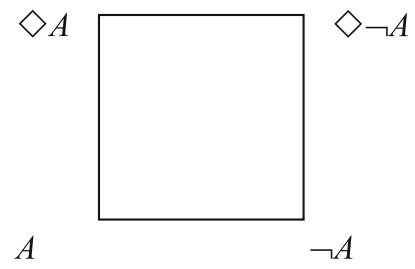

In this square, $\diamond A$ and $\neg A$ are contraries, $\diamond \neg A$ and $A$ are contraries, $\diamond A$ and $\diamond \neg A$ are contraries, $A$ and $\neg A$ are contradictories, $\diamond A$ is a subaltern of $A, \diamond \neg A$ is a subaltern of $\neg A$.

As we see, the Nāgārjunian Square corresponds to Square 5 of Stoics. In turn, Squares 4, 5, and 6 satisfy the modal logic $\mathbf{K}=$ (see "Logical Determinism and hetut $\vec{a}$ " section). In these squares, we deal with another inequality between the weaker and stronger forms of the same modality expressing that something is caused: any strong performance follows from an appropriate weak performance.

The same performances can be denoted by different performative verbs, as we said. In modal logics $\mathbf{T}$ and $\mathbf{K}=$ we treat $\square$ as 'be necessarily' and $\diamond$ as 'be possibly' just technically. The point is that both performative terms came from Scholastic philosophy: necessarius (necessary) and possibilis (possible), therefore we follow tradition of Scholastic modal logic there. The Stoic modal operator $\square$ is translated 'be necessitated' as well as the Nāgārjunian $\square$ (i.e. siddha) is translated 'be necessitated', too, only to distinguish them from the Aristotelian one.

It is common knowledge that philosophical terms cannot be translated literally. The same applies to logic. So, both terms of Indian logic dharma and dharmin denoting logical predicate and logical subject according to their functions do not have these meanings literally. The same is with siddha. This term denotes a strong performance literally, but functionally it can be translated 'be necessitated' within an appropriate formalization of modal reasoning.

\section{Aristotelian Modal Logic}

Any system of modal logic consists of the following vocabulary:

- $p_{0}, p_{1}, \ldots$ - propositional letters (atoms), Prop;

- $\neg, \vee, \wedge, \Rightarrow, \Leftrightarrow-$ propositional connectives: negation ("not...”), disjunction (“... or ...”), conjunction (“... and ...”), implication (if..., then, ...”), equivalence (“... if and only if..."), respectively;

- $\square, \diamond$ - modal operators: the symbol $\square$ is used for "necessity' (“... is necessarily”) or for any other strong performance and the symbol $\diamond$ is for "possibility' ("... is possibly") or for any other weak performance of the same modality.

A well-formed formula of modal logic is defined as follows: 
- Each propositional letter from Prop is a formula;

- If $A$ and $B$ are formulas, then $\neg A, \neg B, A \vee B, A \wedge B, A \Rightarrow B, A \Leftrightarrow B, \square A, \square B, \diamond A$, $\diamond B$ are formulas, as well.

The weakest modal logic, denoted by $\mathbf{K}$ in honor of Soul Kripke, consists of the following axioms/theorems (formulas which are ever proved):

- All propositional axioms/theorems such as $A \vee \neg A$ (excluded middle or tertim non datur), $A \Rightarrow A$ (reflexivity of implication), $(A \wedge B) \Rightarrow B$ (elimination of conjunction), etc.;

- All instances of the Kripke schema: $\square(A \Rightarrow B) \Rightarrow(\square A \Rightarrow \square B)$.

The set of these axioms/theorems is closed under the following two inference rules:

- modus ponens: from $A \Rightarrow B$ and $A$ it follows that $B$;

- Necessitation rule: if $A$ is an axiom/theorem, then $\square A$ is an axiom/theorem, too.

In order to obtain a system of modal logic we can add different additional modal axiom schemes to the set of propositional theorems. The most important of these additional schemes are as follows (Garson 2006):

(K) $\square(A \Rightarrow B) \Rightarrow(\square A \Rightarrow \square B)$

(D) $\square A \Rightarrow \diamond A$

(T) $\square A \Rightarrow A$

(=) $\quad A \Rightarrow \square A$

(CD) $\diamond A \Rightarrow \square A$

The modal logic, denoted by $\mathbf{D}$, has additional schemes (K) and (D). The modal logic, denoted by $\mathbf{T}$, has additional schemes $(\mathrm{K})$ and $(\mathrm{T})$.

It is worth noting that Aristotle might be evaluated as a father of modal logic, because he considered some modal propositions as axioms which are axioms of logic $\mathbf{T}$ in fact. Hence, Aristotle had an inspiration in respect to logical reasoning formalized now within T. Let us show it on some statements from his book Пعрí

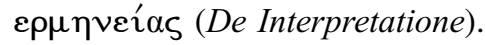

First of all, it is evident for him that if a proposition $A$ is a tautology (it is ever true), then $\square A$ is a tautology, too:

$A \vee \neg A$ is a tautology, then $\square(A \vee \neg A)$ is a tautology, as well.

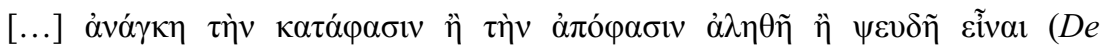

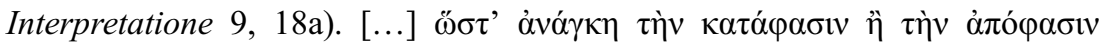

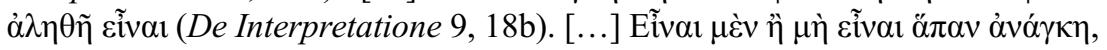

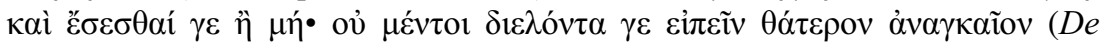
Interpretatione 9, 19a).

[...] Necesse est affirmationem vel negationem veram vel falsam esse (De Interpretatione 9, 18a). [...] Quare necesse est aut affirmationem aut negationem veram esse (De Interpretatione 9, 18b). [...] Esse quidem vel 
non esse omne necesse est et futurum esse vel non; non tamen dividentem dicere alterum necessario (De Interpretatione 9, 19a).

[...] Propositions, whether positive or negative, are true or false necessarily [A.S.: according to the rule of tertium non datur] [...] It may therefore be claimed that it is necessary that affirmations or negations must be either true or false. [...] Everything must either be or not be, whether in the present or in the future, but it is not always possible to distinguish and state determinately which of these alternatives must necessarily come about.

This statement is a basic theorem even for logic $\mathbf{K}$ (it is inferred directly from $A \mathrm{~V}$ $\neg A$ due to the necessitation rule and an introduction of implication). $B$ :

In the meanwhile, Aristotle warned us that we cannot argue $\square A \vee \square B$ from $A \vee$

It is false that if $A \vee B$ is a tautology, then $\square A \vee \square B$ is a tautology, as well.

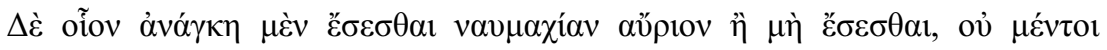

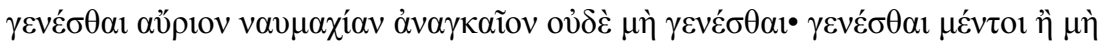

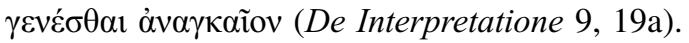

Necesse est quidem futurum esse bellum navale cras vel non esse futurum sed non futurum esse cras bellum navale necesse est vel non futurum esse, futurum autem esse vel non esse necesse est (De Interpretatione 9, 19a).

A sea-fight must either take place tomorrow or not, but it is not necessary that it should take place tomorrow, neither is it necessary that it should not take place, yet it is necessary that it either should or should not take place tomorrow.

Otherwise we would accept that $\diamond A \Rightarrow A$ is ever false and $A \Rightarrow \square A$ is ever true. Nevertheless, we cannot do it in any way:

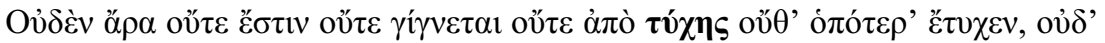

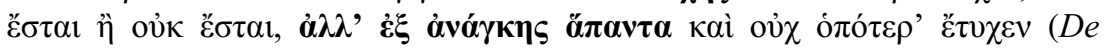

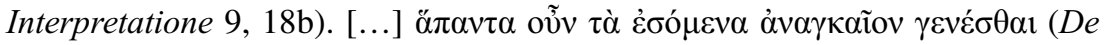
Interpretatione $9,18 \mathrm{~b})$.

Nihil igitur neque est neque fit nec a casu nec utrumlibet, nec erit nec non erit sed ex necessitate omnia et non utrumlibet (De Interpretatione 9, 18b). [...] Omnia ergo quae futura sunt necesse est fiery (De Interpretatione 9, 18b).

Then nothing is or takes place occasionally, either in the present or in the future, and there are no real alternatives; everything takes place of necessity and not occasionally [...]. [...] Then all that is to be must necessarily take place in the future.

According to Aristotle, the proposition $A \Rightarrow \square A$ is always true if and only if $A$ is always true. This takes place only under the following condition: $A$ is a universal affirmation such as 'Each human being is intelligent' that is true indeed at any time. In this case, $A$ does not depend on time and it can be stated truly in any tense: past, 
present, and future. However, if $A$ is an individual affirmation such as 'Socrates is white', we cannot accept $A \Rightarrow \square A$. The main reason is that $A$ is time dependent. Now it can be true, but tomorrow it can be false. Hence, accepting $A \Rightarrow \square A$ for an individual $A$ gives rise to inconsistencies:

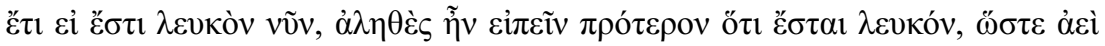

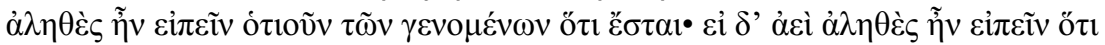

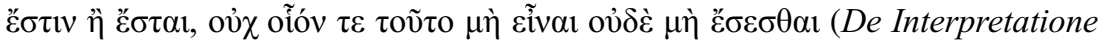
$9,18 \mathrm{~b})$.

Amplius, si est album nunc, verum erat dicere primo quoniam erit album, quare semper verum fuit dicere quodlibet illud eorum quae facta sunt quoniam erit; quod si semper verum est dicere quoniam est vel erit, non potest hoc non esse nec non futurum esse (De Interpretatione 9, 18b).

So, if a thing is white now, it was true before to say that it will be white, so that of anything that has taken place it was always true to say 'it is' or 'it will be'. But if it was ever true to say that a thing is or will be, it is not possible that it should not be or not be about to be.

As we see, Aristotle denied modal axiom (=).

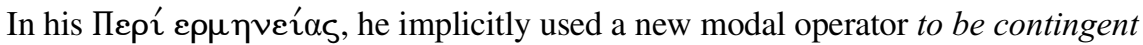

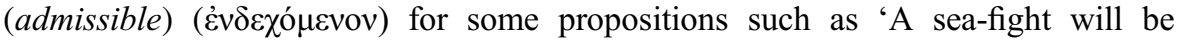

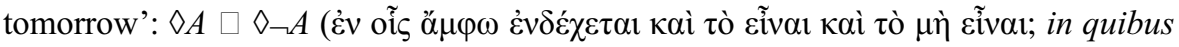
utrumque contingit et esse et non esse). It can be read thus: 'It is possible that $A$ and it is possible that not $A$ '. It means, ' $A$ is contingent'. So, it is possible that a sea-fight will happen tomorrow and simultaneously it is possible that a sea-fight will not happen tomorrow. This event is just contingent.

Some theorems of $\mathbf{T}$ (and of $\mathbf{D}$ ), which were examined as true propositions by Aristotle:

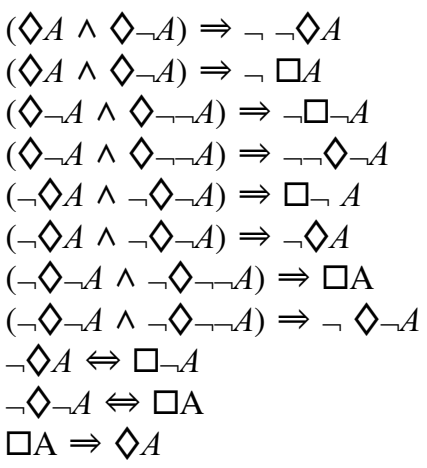

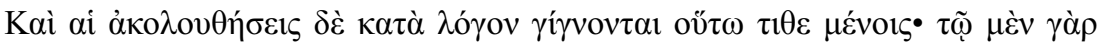

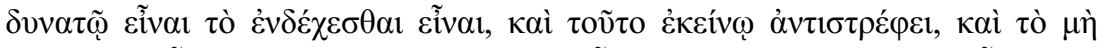

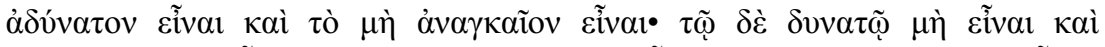

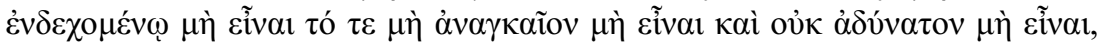

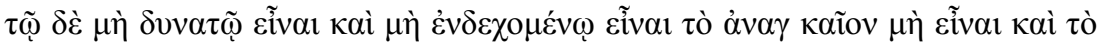

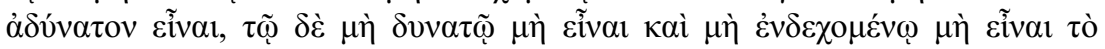




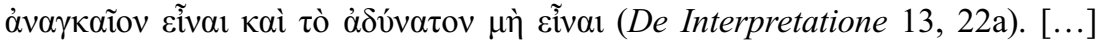

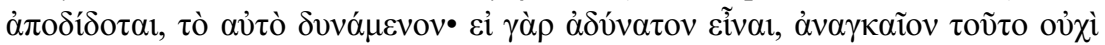

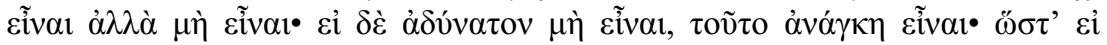

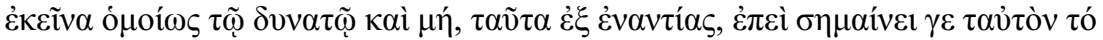

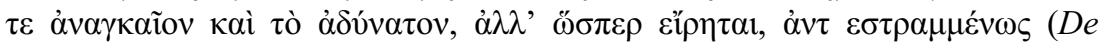

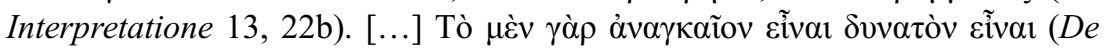
Interpretatione 13, 22b).

Et consequentiae vero secundum ordinem fiunt ita ponentibus: illi enim quae est 'possibile esse' illa quae est 'contingit esse', et hoc illi convertit, et 'non impossibile esse' et 'non necessarium esse'; illi vero quae est 'possibile non esse' et 'contingere non esse' ea quae est 'non necessarium non esse' et 'non impossibile non esse'; illi vero quae est 'non possibile esse' et 'non contingens esse' illa quae est 'necessarium non esse' et 'impossibile esse'; illi vero quae est 'non possibile non esse' et 'non contingens non esse' illa quae est 'necesse esse' et 'impossibile non esse' (De Interpretatione 13, 22a). [...] Nam si impossibile est esse, necesse est hoc non esse sed non-esse; si vero impossibile non esse, hoc necessarium est esse; quare, si illa similiter possibile et non, haec e contrario, nam idem significat 'necessarium' et 'impossibile' sed, quemadmodum dictum est, contrarie (De Interpretatione 13, 22a). [...] Nam quod est necessarium esse, possibile est esse (De Interpretatione 13, 22b).

Implications follow in due course when we have arranged the propositions thus. From the proposition 'contingent to be' it follows that 'admissible to be', and the relation is reciprocal. It follows also 'not impossible to be' [A.S.: $(\diamond A \wedge \nabla A) \Rightarrow \neg \neg \nabla A$ ] and 'not necessary to be' [A.S.: $\left(\diamond_{A} \wedge \diamond_{\neg A) \Rightarrow \neg}\right.$ $\square A]$. From 'contingent not to be' and 'admissible not to be' follow both 'not necessary not to be' [A.S.: $\left(\nabla_{\neg A \wedge} \wedge \neg \neg A\right) \Rightarrow \neg \square \neg A$ ] and 'not impossible not to be' [A.S.: $\left(\nabla_{\neg A \wedge} \wedge \neg \neg A\right) \Rightarrow \neg \neg \nabla_{\neg A}$ ]. From 'not contingent to be' and 'not admissible to be' follow both 'necessary not to be' [A.S.: $(\neg \nabla A \wedge \neg \nabla \neg A) \Rightarrow$ $\square \neg A$ ] and 'impossible to be' [A.S.: $(\neg \nabla A \wedge \neg \nabla A) \Rightarrow \neg \nabla A$ ]. From 'not contingent not to be' and 'not admissible not to be' follow 'necessary to be'

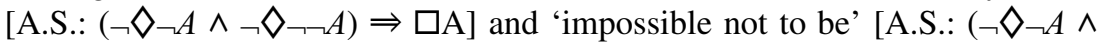
$\neg \nabla A$ ) $\Rightarrow \neg \nabla_{\neg A}$ ]. [...] For 'impossible to be' it is necessary for this (not, to be, but) not to be [A.S.: $\neg \nabla A \Leftrightarrow \square \neg A$ ]; and for 'impossible not to be' it is necessary for this to be [A.S.: $\neg \nabla_{A} A \Leftrightarrow \square A$ ]. Thus if those follow from 'possible' and 'not possible' in the same way, these follow in a contrary way, since 'necessary' and 'impossible' do signify the same but (as we said) when applied conversely. [...] For the necessary to be is possible to be [A.S.: $\square A \Rightarrow \diamond A$, but it is not the case that $\square A \Rightarrow(\diamond A \wedge \nabla A)]$.

Let us define now a Kripke model $M=(X, a, R, V)$ for modal propositions. This model consists of the following components:

- a set $X$ of indices;

- a distinguished index $a$;

- a binary relation $R$ on the indices; 
- a function $V$ assigning a valuation $V(x)$ to each index $x$ and a truth-value $V(x)$ $(A)$ to each index $x$ and atom $A$.

The distinguished index $a$ is to represent an actual time. The relation $R$ is to be said a possibility since $a$. Let us take $x$ from $X$ such that $a R x$. Then this $a R x$ shows us a possibility since $a$ at an index $x$.

A true valuation of formulas at an index $x$ in a model $M$ is defined as follows:

(1) for atomic $A, A$ is true at $x$ in $M$ Iff $V(x)(A)=\mathrm{T}$, where $\mathrm{T}$ means truth

(2) $\neg A$ is true at $x$ in $M$

Iff $A$ is not true at $x$ in $M$

(3) $A \wedge B$ is true at $x$ in $M$

Iff $A$ is true at $x$ in $M$ and $B$ is true at $x$ in $M$

(4) $A \vee B$ is true at $x$ in $M$

(5) $A \Rightarrow B$ is true at $x$ in $M$

(6) $A \Leftrightarrow B$ is true at $x$ in $M$

(7) $\square A$ is true at $x$ in $M$

(8) $\diamond A$ is true at $x$ in $M$

Iff $A$ is true at $x$ in $M$ or $B$ is true at $x$ in $M$

Iff if $A$ is true at $x$ in $M$, then $B$ is true at $x$ in $M$

Iff $A$ is true at $x$ in $M$ if and only if $B$ is true at $x$ in $M$

Iff for all $y$ with $x R y$, $A$ is true at $y$ in $M$

Iff for some $y$ with $x R y$, $A$ is true at $y$ in $M$

A formula $A$ is valid if $A$ is true in all models, and $A$ is satisfiable if $A$ is true in some model. Let us note that $A$ is valid if and only if $\neg A$ is not satisfiable.

To demonstrate an intuitive meaning of $R$ in $M$, we may consider the following example given by Aristotle:

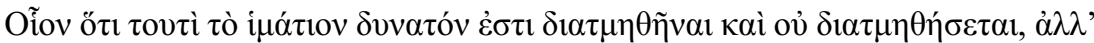

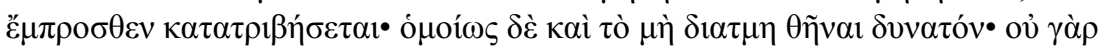

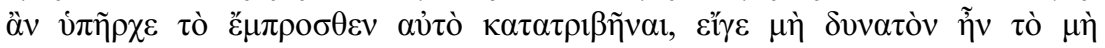
$\delta 1 \alpha \tau \mu \eta \theta \tilde{\eta} v \alpha \mathbf{~ ( D e ~ I n t e r p r e t a t i o n e ~ 9 , ~ 1 9 a ) . ~}$

Ut quoniam hanc uestem possibile est, incidi et non inciditur sed prius exteritur; similiter autem et non incidi possibile est; non enim esset eam prius exteri nisi esset possibile non incidi (De Interpretatione 9, 19a).

It is possible that this coat may be cut in half, but it will not be cut in half, because it will be worn out first. In the same way, it is possible that it is not cut in half; since it would not be possible to wear it out first because of impossibility to cut it in half.

Let $x$ from $X$ be a future point when the proposition $A:=$ 'This coat is cut in half' is true, and let $y$ from $X$ be a future point when the proposition $B:=$ 'This coat is worn out' is true. Then for all $z$ with $x R z, B$ is not true at $z$ in $M$. It means that $\square \neg B$ is true at $z$ in $M$. In the same way, it is readily seen that for all $z$ with $y R z, A$ is not true at $z$ in $M$. It means that $\square \neg A$ is true at $z$ in $M$. In other words, $x R z$ gives all the points $z$ for which it is necessary that this coat is not worn out and $y R z$ gives all the points $z$ for which it is necessary that this coat is not cut in half. Thus, $R$ is to represent a 
sequence of events validating a modal proposition. If there was the event $x$ that this coat was cut in half, then for all subsequent events the proposition 'It is necessary that this coat is not worn out' is true; and if there was the event $y$ that this coat was worn out, then for all subsequent events the proposition 'It is necessary that this coat is not cut in half' is true.

This $R$ can be different for different axioms (Garson 2006):

(K) $\square(A \Rightarrow B) \Rightarrow(\square A \Rightarrow \square B) \quad R$ can be any relation

(D) $\square A \Rightarrow \diamond A \quad R$ is serial: there exist $y$ such that $x R y$

(T) $\square A \Rightarrow A$

$R$ is reflexive: $x R x$

(=) $\quad A \Rightarrow \square A$

$R$ is bisimilar: $x R y \Rightarrow x=y$

(CD) $\diamond A \Rightarrow \square A$

$R$ is unique: $(z R x \wedge z R y) \Rightarrow x=y$

For instance, the theorems of $\mathbf{D}$ correspond to the class of Kripke models in which the relation $R$ is serial. If a formula is a theorem in $\mathbf{D}$, then it is true in all serial Kripke models (this property is called a soundness of $\mathbf{D}$ ); and if a formula is true in all serial Kripke models, then it is provable in $\mathbf{D}$ (this property is called a completeness of D). The truth of $\square A$ at $a$ amounts to the truth of $A$ at all $x$ such that $a R x$, and the seriality of $R$ guarantees that at $a$ there exist $y$ such that $a R y$, so that $A$ will be true at some $y$, too. As a consequence, if $\square A$ is true at $a$, then $\diamond A$ is true at a. As a result, $\square A \Rightarrow \diamond A$ is true.

Assume that $R$ is reflexive, meaning that $x R x$ for all $x$. Then all the theorems of $\mathbf{T}$ are true in $M$ with the reflexive $R$ (soundness) and all true formulas in this $M$ are provable in $\mathbf{T}$ (completeness). The truth of $\square A$ at $a$ means the truth of $A$ at all $x$ such that $a R x$. The reflexivity of $R$ guarantees that $a$ itself will be among these $x$. Therefore, if $\square A$ is true at $a$, then $A$ is true at $a$, as well. Thus, $\square A \Rightarrow A$ is true.

It is worth noting that if $R$ is reflexive, then $R$ is serial. From this it follows that the class of Kripke models in which the relation $R$ is reflexive includes the class of Kripke models in which the relation $R$ is serial. So, from axiom (T) we can infer axiom (D). It means that $\mathbf{T}$ is an extension of $\mathbf{D}$.

In his works, Aristotle considered many modal propositions which are provable in $\mathbf{T}$ and therewith true in Kripke models in which the relation $R$ is reflexive. Later these propositions were analyzed in medieval scholastic philosophy. We have to be honest and frank about saying that these propositions of $\mathbf{T}$ do not occur in classical Indian philosophical treatises at all. Nevertheless, we can face many correct modal propositions corresponding to axioms of the modal logic, denoted by $\mathbf{C D}$, with additional modal schemes (K) and (CD). And for the first time, these propositions can be reconstructed on Nāgārjuna's texts.

\section{Logical Determinism and hetutā}

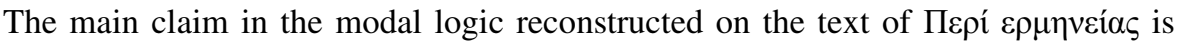
that there exists contingency: $\diamond A \wedge \nabla_{A} A$. Contingent events were called by

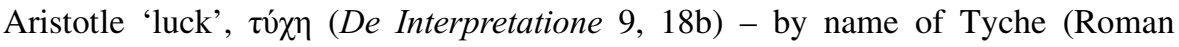
equivalent: Fortuna), the goddess of luck and destiny. These events are possible 
only in modal logic $\mathbf{T}$ (and $\mathbf{D}$ ). The negation of contingency gives to rise a logical determinism: $\neg(\diamond A \wedge \diamond \neg A)=\neg \diamond A \vee \neg \diamond \neg A=\square \neg A \vee \square A=\square A \vee \square \neg A$ so that if there is no contingency, then each event is necessary to be or it is necessary not to be: $\square A \vee \square \neg A$.

Let us notice that besides $\mathbf{T}$ and $\mathbf{D}$ there are modal logics $\mathbf{K}=$ and $\mathbf{C D}$. The logic, denoted by $\mathbf{K}=$, has additional modal schemes $(\mathrm{K})$ and $(=)$. The modal logic, denoted by CD, has additional modal schemes (K) and (CD).

Suppose that $R$ is bisimilar: $x R y \Rightarrow x=y$. Then all the theorems of $\mathbf{K}=$ are true in $M$ with the bisimilar $R$ (soundness) and all true formulas in this $M$ are provable in $\mathbf{K}=$ (completeness). Let us assume the truth of $A$ at $a$. The truth of $\square A$ at $a$ would mean the truth of $A$ at all $x$ such that $a R x$, but for all $a R x$ we have that $a=$ $x$ according to the property of $R$. Then $A \Rightarrow \square A$ is true. Now let $R$ be unique: $(z R x \wedge$ $z R y) \Rightarrow x=y$. In this case all the theorems of $\mathbf{C D}$ are true in $M$ with the unique relation, $R$ (soundness) and all true formulas in this $M$ are provable in CD (completeness). The truth of $\diamond A$ at $a$ would mean the truth of $A$ at some $x$ such that $a R x$, and the truth of $\square A$ at $x$ would mean the truth of $A$ at all $y$ such that $x R y$. Because of the property of $R$ we have for these (some) $x: x=y$. Then $\diamond A \Rightarrow \square A$ is true.

In both $\mathbf{K}=$ and $\mathbf{C D}$ the following propositions are theorems:

(CD) $\diamond A \Rightarrow \square A$

(CD1) $\square(A \vee B) \Rightarrow(\square A \vee \square B)$

(CD2) $(\square A \vee \square B) \Rightarrow \square(A \vee B)$

(CD3) $\square(A \Rightarrow B) \Rightarrow(\square A \Rightarrow \square B)$

(CD4) $(\square A \Rightarrow \square B) \Rightarrow \square(A \Rightarrow B)$

(CD5) $\square(A \wedge B) \Rightarrow(\square A \wedge \square B)$

(CD6) $(\square A \wedge \square B) \Rightarrow \square(A \wedge B)$

For more details, see (Garson 2006). Hence, in logics $\mathbf{K}=$ and $\mathbf{C D}$ we can deduce that the proposition $\square A \vee \square \neg A$ is a theorem. Indeed, $A \vee \neg A$ is a propositional axiom/theorem. Then $\square(A \vee \neg A)$ is a theorem, too, by the necessitation rule. According to (CD1), the proposition $\square(A \vee \neg A) \Rightarrow(\square A \vee \square \neg A)$ is a theorem. By modus ponens we conclude that $\square A \vee \square \neg A$ is a theorem of $\mathbf{K}=$ and $\mathbf{C D}$. Hence, in logics $\mathbf{K}=$ and $\mathbf{C D}$ no contingent events are possible. The proposition $\diamond A \wedge \diamond \neg A$ is always false.

Let us show that if $R$ is bisimilar, then $R$ is unique, i.e. the class of Kripke models in which the relation $R$ is bisimilar includes the class of Kripke models in which the relation $R$ is unique. Let us take the bisimilar $R$ for $z R x$ and $z R y$. Then $z=x$ and $z=$ $y$. From this it follows that $x=y$. Thus, from axiom (=) we can infer axiom (CD). In other words, $\mathbf{K}=$ is an extension of $\mathbf{C D}$.

Among the Greek philosophers the majority accepted the existence of contingency,

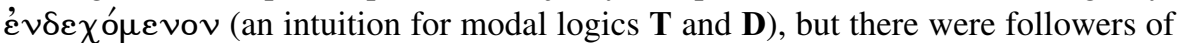
logical determinism, also (an intuition for modal logics $\mathbf{K}=$ and $\mathbf{C D}$ ). Stoics are the most prominent among these followers.

The main modal postulate proposed by Chrysippus, who became the most prominent Stoic logician, is as follows: 
$\left(\mathrm{S}_{1}\right)$ Nihil enim fieri sine causa potest (Cicero: De Divinatione 2, 61).

Nothing happens without a cause.

Motum nullum esse sine causa (Cicero: De Fato 23).

No motion is without a cause.

To understand what it means, we should note that for the Greek philosophers, each individual proposition $A$ is time dependent. Hence, the semantic statement ' $A$ is true' ( $A \dot{\alpha} \lambda \eta \theta \dot{\varepsilon} \zeta \dot{\varepsilon} \sigma \tau \imath$ ) always means ' $A$ is true now'. For instance, 'Aspasia is walking' is true if Aspasia is now walking and it takes place due to a cause that might be explored. All the future propositions such as 'Aspasia will walk tomorrow' or 'A sea-fight will take place tomorrow' can be evaluated only now, whether recently they are true owing to some reasons. Hence, they are true now if and only if now there are some causes determining these events tomorrow.

An emergence of cause implies an effect. If this effect is described by an

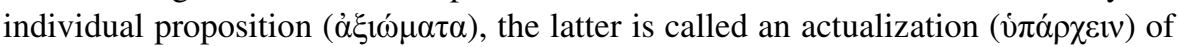
predicate, see (Bobzien 1998). Examples of predicates are as follows: 'to walk', 'to be alive', 'to be cut in half', and 'to be worn out'. If we observe some events such as walking, being alive, being cut in half, and being worn out, respectively, as effects of some causes, the predicates 'to walk', 'to be alive', 'to be cut in half', and 'to be worn out' are actualized now and we can express them in individual propositions truly. For instance, 'to walk' is actualized if Aspasia is walking now for some reasons. These actualized predicates are called then attributes $(\sigma \cup \mu \beta \varepsilon \beta \eta$ кó $\tau \alpha)$ (see Stobaeus: Eclogarum physicarum et ethicarum I 106, $20-23)$. So, due to $\left(\mathrm{S}_{1}\right)$ at any one time each individual proposition can contain an actualized and deactualized predicate to be either true or false:

$\left(\mathrm{S}_{2}\right)$ Each individual proposition ( $\left.\dot{\alpha} \xi \omega \dot{\omega} \mu \alpha \alpha\right) A$ (even about future) is either true or false: $A \vee \neg A$.

From $\left(\mathrm{S}_{2}\right)$ the Stoics infer as follows:

$\left(\mathrm{S}_{3}\right)$ Each individual proposition (even about future) $A$ is necessarily true or it is necessarily false: $\square \mathrm{A} \vee \square \neg A$.

Thus, according to the Stoics, modal logics $\mathbf{K}=$ and $\mathbf{C D}$ are more natural than logics T and D. Some Stoic synonyms for the word 'necessity' ( $\alpha \dot{\alpha} \gamma \kappa \kappa)$ : 'inexorable'

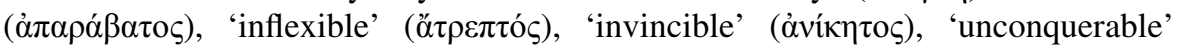

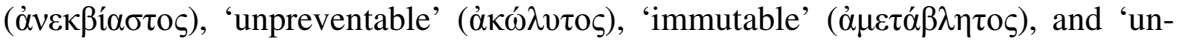

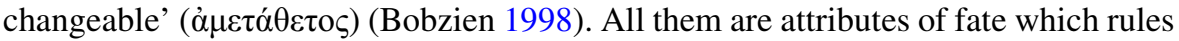

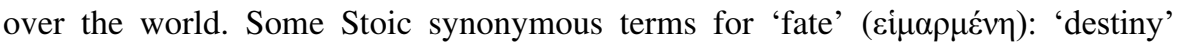

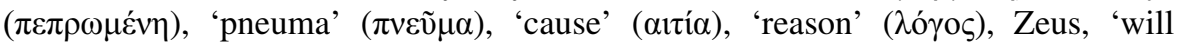
( $\beta$ ov́ $\lambda \eta \sigma ı)$ of Zeus'. Due to the fate, each event has its cause. So, each event should be regarded as actual as if it happens in the present tense.

$\left(\mathrm{S}_{4}\right)$ Each (past, present, future) event $A$ is actual and then necessary: $A \Rightarrow \square A$. 
Let us take the bisimilar relation $R: x R y \Rightarrow x=y$. The event $a$ represents an actual time. So, if the proposition $A$ is true at $a$, then $A$ is necessary for the bisimilar $R$ : $\square A$ is true at $a$. Furthermore, the $R$ makes all events actual.

The same epiphany of bisimilar $R$ came to the Stoics - as we see. According to them, making all events actual and all actual events necessary, fate can be called

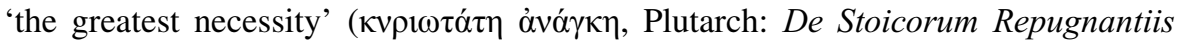

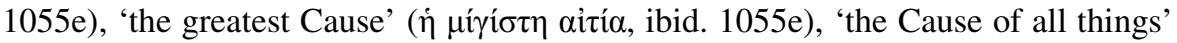

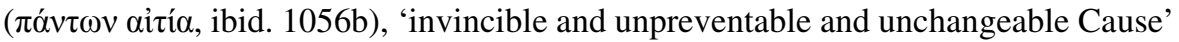

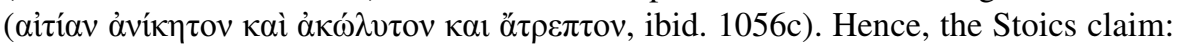

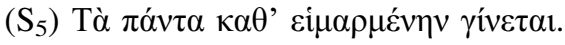

Everything happens in accordance with fate.

First of all, it means that the universe is a causal network. This network is called by

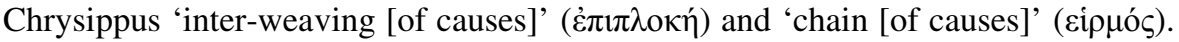
Within the network, every event is 'necessitated' ( $\alpha \alpha \alpha \alpha \alpha \gamma \kappa \alpha ́ \zeta \varepsilon \sigma \theta \alpha \mathrm{l})$ or 'happened

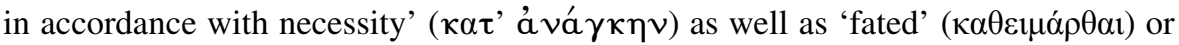
'happened in accordance with fate' ( $\kappa \alpha \theta$ ' $\varepsilon i \mu \alpha \rho \mu \varepsilon ́ v \eta \nu)$ (Bobzien 1998).

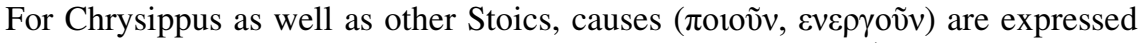

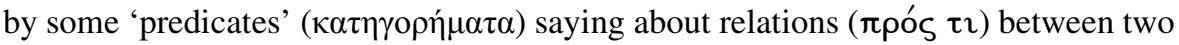
corporeal bodies: the first one that affects and the second one that is caused. Causes can be used for explanations (logical inferences): 'that because of which' ( $\delta \imath$ ' ô). Formally, causes can be represented as relations $r_{t p}(x, y)$ at a time $t$ and at a place $p$ among corporeal bodies $x$ and $y$ with an antecedent $x$ affecting on a body of $y$ at $t$ and $p$ and a succedent $y$ being a result of this affecting. Each body from $r_{t p}(x$,

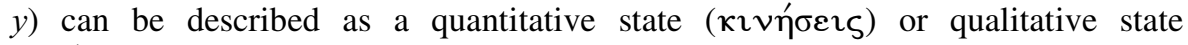

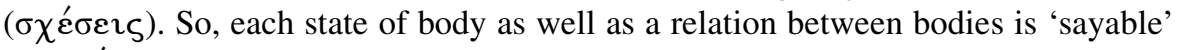
( $\lambda \varepsilon \times \tau$ 'a $)$ - it is worth noting that this 'to be sayable' is the only incorporeal thing of our universe for the Stoics. Let us quote how causes are treated in the Stoic fragments:

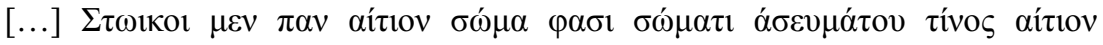

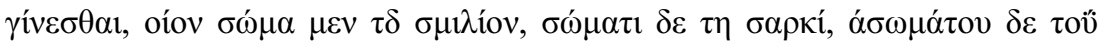

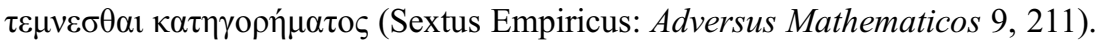

[...] the Stoics say that every cause is a body which becomes a cause, to a body, of something incorporeal; as for instance the scalpel, which is a body, becomes a cause, to the flesh, which is a body, of the incorporeal predicate 'being cut'.

Hence, (=) as an axiom of $\mathbf{K}=$ is understood as a tautology by the Stoics, too, see $\left(S_{4}\right)$ and $\left(S_{5}\right)$. The statement about possibilities with the same logical meaning is as follows ( $\mathbf{K}=$ can be obtained by adding $(\mathrm{K})$ and $(=2)$ to the propositional axioms):

$$
(=2) \diamond A \Rightarrow A
$$

According to the Stoics, a proposition $A$ is possible now, i.e. $\diamond A$, if and only if nothing external hinders it from happening at some time from now on, see (Bobzien 1998). For instance, the proposition 'this coat will be cut in half' is possible from 
now on if and only if there exists the coat that was not worn out yet. In this case 'being worn out' is an effect of something external that hinders the event 'being cut in half' from happening. Let us pay attention that we have the following two general conditions: (i) an event is actual $(A)$ if and only if there is a cause now that affected on the happening of this event; (ii) an event is possible $(\diamond A)$ if and only if there are no causes now which hinder this event from happening. As we see, the condition (i) is more general than (ii): (ii) $\Rightarrow$ (i), i.e. we deal with (=2), but in the Stoic terms:

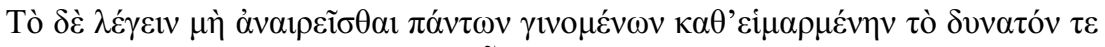

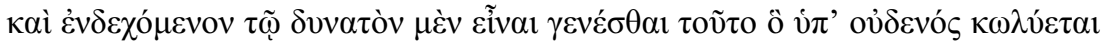

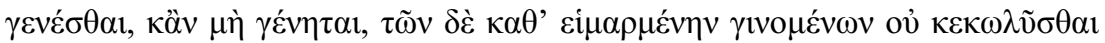

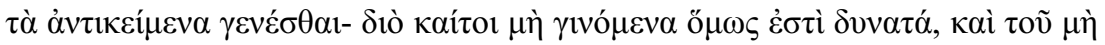

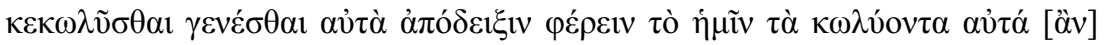

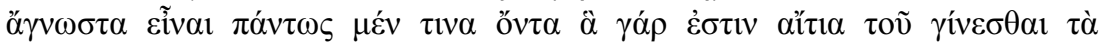

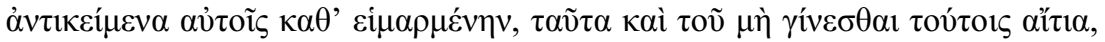

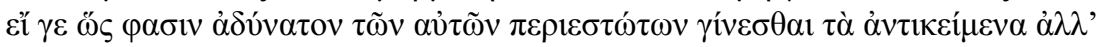

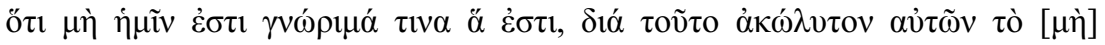

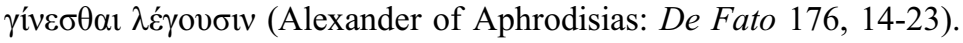

But to say that the possible and the contingent are not avoided if everything happens in accordance with fate [A.S.: see $\left(S_{4}\right)$ and $\left(S_{5}\right)$ ], since that is possible to happen which is hindered by nothing from happening even if it does not happen, and that the contradictories of the things that happen in accordance with fate are not hindered from happening $<$ and to say that $>$ for this reason those things that do not happen are equally possible [A.S.: $\diamond A \vee \diamond \neg A$ ], and to put forward as proof of their not being prevented the fact that the things that hinder them are unknown to us, although there certainly are some, namely the causes of their contradictories happening in accordance with fate, which are also the causes of their not happening (since, as they say, it is impossible that in the same circumstances contradictory things happen); but since it is not known to us what they are, because of this, they say, the things that do not happen are not hindered from happening (Bobzien 1998).

Thus, the Stoics have accepted the following two modal axioms: (=) and (=2), i.e. the logic $\mathbf{K}=$. It means they have followed the logical determinism and avoided any contingency. The same logical determinism is observed in the Yogācāra texts, but it is put forward by means of other postulates. So, instead of the concept of motion proposed by the Stoics in $\left(S_{1}\right)$, the Yogācārins have introduced the new term arthakriyātva:

$\left(\mathrm{Y}_{1}\right)$ There is arthakriyātva (a causal efficacy as a criterion to be real).

hetupratyayānām eva tarhi sāmarthyam paśyāmaḥ, sati sāmagrye bhāvād asati cābhavān na jāter iti hetupratyayā eva janakāḥ santi

(Vasubandhu: Abhidharmakośabhāṣya 79, 19-21), see (Pradhan and 1967).

So, we see the causal efficiency only of causes and conditions. [It is the case] of origination, because when the [causal] complex is given, there is existence, 
and when not there is non-existence. Therefore, only the causes and conditions are bringing forth.

\section{arthakriyāsamartham yat tad atra paramārthasat I} anyat samvrntisat proktam te svasāmānyalakșaṇe II

(Dharmakīrti: Nyayabindu 14-15), see (Dharmottarapradipa 1971).

To have a real existence (paramärthasat) an entity should have some causal powers (arthakriyāsamartha) there. Other entities are declared to be customarily existent (samvrtisat). These two [i.e. the real notion and the customary notion] are [respectively] particulars and generals.

According to this arthakriyâtva, everything what actually exists is fully subordinated to causality (hetutā): each real entity should have a cause, on the one hand, and an effect, on the other hand. As we see, the Yogācāra assumption of ( $\left.\mathrm{Y}_{1}\right)$ is even stronger in principle than the Stoic assumption of $\left(\mathrm{S}_{1}\right)$. In the meanwhile, by the Yogācārins there are two logical terms: the particular (svalakṣaṇa) that expresses real entities and the general (sāmānyalakșana) which is unreal and used for our inferences to characterize and generalize an appropriate particular.

So, due to $\left(\mathrm{Y}_{1}\right)$, each event can be considered 'being a cause (upajīvyatva)' or 'being an effect (upajivakatva)'. Between them, i.e. between a cause $A$ and an effect $B$, there is a necessary connection (sambandha) $A \Rightarrow B$ which can be articulated in our desire to know which is the reason of treating inference after perception of $B$ (anumānajñānam me bhavatu, 'let me have knowledge of inference)'. In turn, the knowledge of inference produces what is desirable for me (anumānajñānam madiștasādhanani) (Vattanky 2003). As a result, my claim (sādhya) about the causal connection $A \Rightarrow B$ is expressed in the form that at a locus (pakșa) $x$ there is the property (dharma) $A$ of a subject (dharmin) $x$, because at this locus $x$ there is the sign (linga) $B$ :

(1) The udāhārana: $A \Rightarrow B$

'Whatever is fiery $(A)$, is smoky $(B)$ '.

(2) The upanayana:

'This hill is smoky' - at the locus $x$ ('hill') there is the sign (linga or hetu) $B$ ('smoky')

(3) The niggamana:

'Therefore it is fiery' - at the locus $x$ there is the property (dharma) $A$ ('fiery').

The causal connection between 'fiery' and 'smoky' is represented by the implication: 'If fiery, then smoky', but our inference is based on a sign of 'smoky' and it has the form of converse: 'If smoky there, then fiery there'. Hence, the implication for the Yogācārins, first, can connect events $A$ and $B$ and then we have: 
$A \Rightarrow B$, and, second, the implication can connect signs $A$ and $B$ and, as a result, there is a converse: $B \Rightarrow A$.

The same situation of two possible implications with the same content was known by the Stoics. Their examples of reasoning based on signs: 'If this one has milk in her breasts, she is pregnant', 'If sweat flows through the surface, then there are imperceptible pores', 'If this one has a scar, he has had a wound' (cf. Sextus

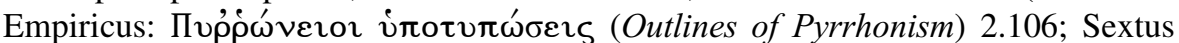
Empiricus: Adversus Mathematicos 8. 252; 254-255, 309). In all these cases the causal relationships are expressed by converses: 'If this one is pregnant, she has milk in her breasts', 'If there are imperceptible pores, then sweat flows through the surface', 'If this one has had a wound, he has a scar'.

For the Yogācārins, each claim (sādhya) about a causal relationship is either true or false to the same extent as for the Stoics - see $\left(S_{2}\right)$ :

$\left(\mathrm{Y}_{2}\right)$ Each claim (sādhya) that a poperty $P$ (dharma) belongs to a subject $S$ (dharmin) is either true or false: ' $S$ is $P$ ' $\vee \neg$ ' $S$ is $P$ '.

This statement is equivalent to the following:

$\neg($ ' $S$ is $P$ ' $\wedge \neg$ ' $S$ is $P$ ')

$\neg($ ' $S$ is $P$ '^ 'S is $\neg P$ ')

viruddhayor ekadharminy ayogād astu bādhanam I viruddhaikāntike nātra tadvad asti virodhitā II (Tillemans 2000), p. 92.

Since two contradictory [properties (dharma)] [A.S.: $P$ and $\neg P$ ] cannot occur in one subject (dharmin) [A.S.: S], let us grant that there is invalidation of the antinomic [reason] (yiruddhaikāntika). [But] there is no contradiction like that here (Tillemans 2000), p. 92.

Furthermore, the claim ( $s \bar{a} d h y a)$ about a causal relationship is either necessarily true or it is necessarily false in the same way as for the Stoics - see $\left(\mathrm{S}_{3}\right)$ :

$\left(\mathrm{Y}_{3}\right)$ Each claim (sādhya) that a poperty $P$ (dharma) belongs to a subject $S$ (dharmin) is either necessarily true [it expresses a necessarily connection, svabhāva, between $S$ and $P]$ or it is necessarily false: $\square$ 'S is $P$ ' $\vee \square \neg$ 'S is $P$ '.

lingam svabhāvah kāryam vā dṛśyādarśanam eva vā| sambaddhạ̣ vastutah siddham tad asiddham kim ātmanaḥ II (Tillemans 2000), p. 20.

A [valid] reason, which is necessarily connected [with the property to be proved], can only be an essential property (svabhāva) or an effect (kārya) or a nonperception of something perceptible (drśsyadarśana). Why is this [reason, viz., utpattimattvādi,] which is established in reality, not established for oneself [i.e., for the Sāṃkhya]? (Tillemans 2000), p. 20.

According to the Sarvāstivādins, each existing item (corporeal body) goes through the three moments (kșaṇa) of all its life: origination, duration, and destruction. 
uppādațthitibhañgavasena khanattayam ekacittakkhaṇam nāma. tāni pana sattarasa cittakkhañāni rūpadhammānam āyu (Anuruddha: Abhidhammatthasangaha 4, 3) (Rospatt 1995), p. 39.

The three moments [required] on account of origination, duration and destruction are called 'the moment of (i.e. taken by) one mental event' (citta). The lifetime of material entities is seventeen of these moments of a citta (Rospatt 1995), p. 39.

Only such items (i.e. momentary events, kșana, with origination, duration, and destruction) can be causally efficient - they are caused by one items and have affects on other items. All the permanent (non-momentary) entities do not exist and stay out of causality. Let us consider the Dharmakīrti's example of permanent entities: 'Rabbit's horns (śaśavișāna)'. This entity does not exist, as far as we know: $\neg A$, where $A:=$ 'rabbit's horns'. As consequence, it has no cause and cannot affect other things. So, it stays out of causality, indeed, so that there is no cause making the rabbit's horns existing and then we can assert: 'It is impossible that there are rabbit's horns' ( $\neg A$, where $A:=$ 'rabbit's horns'). Hence, from $\neg A$ Dharmakīrti implicitly infers $\neg \diamond A$ :

$$
(=3) \neg A \Rightarrow \neg \triangleright A
$$

In the basic modal logic $\mathbf{K}$, from (=3) there are inferred (=) and (=2). So, adding $(=3)$ to $\mathbf{K}$ gives for us the system $\mathbf{K}=$ in the same way as adding (=) or (=2) to $\mathbf{K}$ implies obtaining the logic $\mathbf{K}=$ for the logical determinism.

For the Sarvāstivādins all conditioned entities (samskṛta, samskāra) are present for a moment, but for the Yogācārins they exist for a moment (Rospatt 1995), p. 39. At this moment they manage to function as efficient causes - in the words of Yogācārins: "they realize their own fruit". If there is an uninterrupted flow of causally connected momentary entities of the same kind, they constitute santāna or citta-santāna - a stream or mind-stream in the meaning close to the stream of phenomena defined by Edmond Husserl in the $20^{\text {th }}$ century A.D.

We can easily note that the Yogācārins have examined 'being momentary' as 'being actual' or 'being just now'. Due to this momentariness, each conditioned entity was actual in the past or it is actual in the present or it will be actual in the future. This implies that each entity has own causes and since that it is necessitated in fact - please compare to $\left(\mathrm{S}_{4}\right)$ :

$\left(\mathrm{Y}_{4}\right)$ Each (past, present, future) event $A$ is actual (momentary) and then necessary: $A \Rightarrow \square A$.

The momentariness of all real beings is explained by the Yogācārins by the momentariness of our mind (citta) as an ultimate observer of all appropriate moments:

kṣanikam hi cittam prasiddham, tasya cānye samskāāāś cakșūrūpādayo hetutah. tasmāt te 'pi kșaṇikā iti siddham. na tv akșanikāt kșaṇikam bhavitum arhati, yathā nityād anityam iti 
(Vasubandhu: Mahāyānasūtrālaṃkārabhāṣya 151, 1-3), see (Exposé de la doctrine du Grand Véhicule 1907).

The mind (citta) is commonly known to be momentary (ksanika), as well as the other conditioned factors (samskāra): the eye, the visible and so on as its cause. Therefore, it is proved that they also are momentary. Nevertheless, it is not possible that something momentary [such as mind] originates out of something non-momentary, as it is said (iti) [to be impossible that] something impermanent [originates] out of something eternal.

Quite similar:

If the soul were unchangeable, then, even at the moment of the rise of a cognition, the soul would remain the same as in its [previous] state of being a noncognizer (apramātr), and it could not be a cognizer (pramātr ) (Hattori 1968), p. 69.

So, first of all, our mind (citta) is momentary (kșanika) at all steps of our observations and only therefore all corporal bodies are momentary, as well. Hence, momentariness (kșanikatva) means for the Yogācārins that at one moment (kșaṇa) a cause, its effect and their observer meet each other.

The Stoics, for justifying the logical determinism of axiom $\left(\mathrm{S}_{4}\right)$, have appealed to fate - an ultimate personified or depersonified observer who contemplates all causal relationships, see $\left(\mathrm{S}_{5}\right)$, while the Yogācārins have supposed a momentary mind scattered everywhere and put forward the following statement:

$\left(\mathrm{Y}_{5}\right)$ Everything is momentary.

As we see, the Yogācārins have accepted two modal axioms: first, (=) in the form of $\left(\mathrm{Y}_{4}\right)$; and, second, $(=2)$ in the form of (=3), i.e. the modal $\operatorname{logic} \mathbf{K}=$, as well as the Stoics have done the same. Nevertheless, an appropriate philosophy of logical determinism proposed by the Yogācārins was even much more theoretical than the Stoic philosophy. In any case, this Yogācāra discourse has been at the root of establishing logic (nyāya) in India. In the Nyāyasūtra, the first logical treatise, we find a lot of quotations from different texts of Madhyamaka and Yogācāra schools, see some examples in (Vidyabhusana 1921), pp. 46-47. These quotations prove that the Nyāyasūtra was written in the second century A.D. in the Kușanna Empire - at the time and place of writing the early Madhyamaka and Yogācāra texts. In this treatise, we see even the Madhyamaka manner of refutation of the God existence probably taken from the Nāgārjuna's İ́svara-kartṛtva-nirākrttihh-viṣnoho-ekakartṛtvanirākarana:

īśvaraḥ kāraṇam, puruṣakarmāphalyadarśanāt $\|19\|$

na, puruṣakarmābhāve phalāniṣpatteh \|20\|

tatkāritatvād ahetuh \|21\|

(Nyāyasūtra 4.1.19-21), see (Gautama 1936). 
Ísvara is a reason for observing that human actions are fruitless. Wrong, because without human actions there is no "fruiting". Not an argument - due to the conditionality of the latter.

Formally: If the Lord (iśvara) is a cause $(A)$, then human actions are without fruits $(B)$. Nevertheless, they are ever with fruits $(\neg B)$. Then the Lord is not a cause $(\neg A)$ :

$$
(A \Rightarrow B) ; \neg B
$$

$\neg A$.

The Mādhyamikas and Yogācārins were atheists. Therefore the Yogācārins have refuted any personified way of describing the logical determinism - they have not used the Stoic terms like fate, destiny, God. The Yogācāra term of momentariness (kșanika) denotes a moment of meeting a cause, its effect and their observer. So, we do not need any assumption of the God existence as a guarantee of causality. Sometimes, the Stoics have tried to describe the logical determinism in a depersonalized manner too by means of the term of cóvos ('tension'), a momentary movement of pneuma $(\pi v \varepsilon \tilde{v} \mu \alpha)$ at all things causing their attraction and repulsion, on the one hand, and an observation of appearing a causal relationship then and there, on the other hand.

Later, the Naiyāyikas (such as Udayana in his Nyāyakusumāñjali) have supposed that for the validity of logical determinism we should accept the existence of God. According to Udayana, there is always an antecedent fact existing prior to an event which determines when this event should begin to be (niravadhitve aniyatāvadhikatve vā kādācitkatvavyāghātāt) (Bhattacharyya 1961). If there is no effect, it means that at that moment there is no cause. So, we have two implications: 'If a cause $(A)$, then an effect $(B)$ '; 'If no effect $(\neg B)$, then no cause $(\neg A)$ ' $(A \Rightarrow B$; $\neg B \Rightarrow \neg A$ ). At each locus called pakssa we can observe an appropriate effect $B$ to draw a suitable causal inference: 'If there is the cause $A$ at the locus (pakșa), then there is the effect $B$ at the same place and at the same time'. This $B$ is a determinate concomitant (vyāpya) of $A$. So, this $B$ at the locus allows us to conclude that there is the cause $A$ of $B$ (sādhya), also. But in this inference we deal with an instance (drsțtanta) that in the locus there is the causality: 'If $A$, then $B$ ' $(A \Rightarrow B)$. Hence, we deal always with particular instances at different loci, but we infer assuming that they implement a general case of causality of that type (sāmānyatah sädhyasiddhi). In other words, our inferences concern loci and then they are particular in its character (viśeșanumāna), but we ever suppose that they are general in its character (sāmānjānumāna). According to the Naiyāyikas, God is a supervisor and guarantor allowing any observer to see general inferences in particular ones. He is founding causality as such at each moment and $\mathrm{He}$ is a supervisor of all forms of causal connections among things in the same way as "the wood-cutter is seen to supervise the axe in the act of cutting" (Bhattacharyya 1961). As a consequence, God is an intelligent author of causality as a general law (which is adrșta, immaterial), but we see only its particular examples among material things. This reasoning of Naiyāyikas gives a personification of logical determinism in the spirit of Stoics 
Table 1

\begin{tabular}{|c|c|c|c|}
\hline & Stoics & Yogācārins & Naiyāyikas \\
\hline $\begin{array}{l}\text { Depersonification } \\
\text { of logical } \\
\text { determinism, } \\
\text { atheistic approach }\end{array}$ & 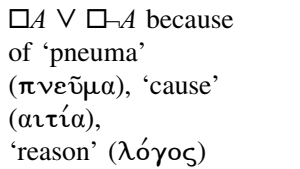 & $\begin{array}{l}\square A \vee \square \neg A \text { because of } \\
\text { momentariness (ksanikatva) } \\
\text { - at one moment a cause, } \\
\text { its effect and their observer } \\
\text { meet each other }\end{array}$ & - \\
\hline $\begin{array}{l}\text { Personification } \\
\text { of logical } \\
\text { determinism, } \\
\text { theistic approach }\end{array}$ & 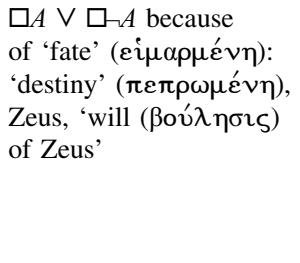 & - & $\begin{array}{l}\square A \vee \square \neg A \text { because } \\
\text { of God who is the } \\
\text { highest supervisor } \\
\text { of all non-empirical } \\
\text { objects }(a d r s t a) \text { which } \\
\text { are being involved } \\
\text { into explanations } \\
\text { by causality }\end{array}$ \\
\hline
\end{tabular}

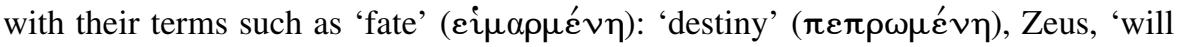
(ßov́ $\lambda \eta \sigma \imath \varsigma)$ of Zeus'.

Thus, the Stoics have based on different moods of understanding the logical determinism at once: personified and depersonified, but the Yogācārins have preferred only the depersonified (atheistic) mood, while the Naiyāyikas have followed only the personified (theistic) mood, see Table 1.

\section{Nāgārjuna's Intuition towards Modal Logic}

The atheistic approach of Yogācārins can be explained, first of all, by their modal intuition that the logical determinism holds true everywhere - this position shared by them was strongly opposed to the Hinduism of the first purāna texts. The point is that at the time of the early Madhyamaka and Yogācāra, the religion based on the ideas of different purāna texts became quite popular among common people and, according to these ideas, in our world there are ever possible divine miracles, because there can be ever born some mighty deities among us such as Kṛ̣ṇa or Rāma who can perform miracles at any moment. These deities can work wonders for our protection or just for their own sake. The Mādhyamikas and Yogācārins were pitting themselves against the purānic faith in miracles and magic. The existence of miracles would mean the existence of contingency, but according to the logical determinism there is no place for contingency in the world.

In the Íśvara-kartrtva-nirākṛtih-viṣnoh-ekakartrtva-nirākaraṇa (Stcherbatsky 1969), Nāgārjuna criticizes the purānic faith from the point of view of modal $\operatorname{logic} \mathbf{K}=$. It is one of the earliest philosophical texts in India assuming a modal logic. Then the ideas of this short treatise were well developed by the Yogācārins presenting the logical determinism even more explicitly.

Nāgārjuna begins with the following postulate:

$\left(\mathrm{N}_{1}\right)$ Everything is either siddha or asiddha. 
In (Stcherbatsky 1969), Th. Stcherbatsky translates siddha as 'existent' and asiddha as 'non-existent'. Nevertheless, siddha (as well as its negation, asiddha) has an additional modal aspect: siddha means something that was resulted from a committed act or something that is reliable because of evidence through our thought. This modal aspect is quite close to the following Stoic logical terms: 'to be

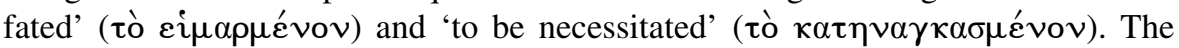
Stoics distinguish the term 'to be necessitated' from the term 'that which is necessary' ( $\tau$ ò á $v \alpha \gamma \kappa \alpha \tilde{\tau} o v)$. We can say that 'to be necessitated' is an a posteriori necessity, while 'that which is necessary' is an a priori necessity. The Stoic claim of $\left(\mathrm{S}_{3}\right)$ that each individual proposition (even about future) $A$ is necessarily true or it is necessarily false: $\square A \vee \square \neg A$, concerns only the a posteriori necessity. It means that de facto we have that $\square A \vee \square \neg A$, not in advance. Claim $\left(\mathrm{S}_{3}\right)$ of the Stoics holds true only because of causality - see $\left(\mathrm{S}_{1}\right)$.

The Nāgārjuna's term siddha is not sat ('existent'), but something that was caused - see the Yogācāra postulate of $\left(\mathrm{Y}_{1}\right)$. Therefore claim $\left(\mathrm{N}_{1}\right)$ should be understood as follows:

$\left(\mathrm{N}_{2}\right)$ Each event $A$ happens necessarily (siddha) or it does not happen necessarily (asiddha): $\square A \vee \square \neg A$.

Indeed, Nāgārjuna states that between both terms siddha and asiddha there is a mutual contradiction (paraspara-virodha):

yaḥ siddhặ saḥ siddhạ̣ eva. yaḥ tu asiddhạ̣ sạ̣ eva asiddhaḥ. evam tadanayoh paraspara-virodhaḥ syād eva. yathā ca āloka-andhakārayoḥ jīvana-maraṇayoh iva. atha yatra ālokaḥ vidyate tatra andhakāraḥ na asti. yatra andhakārah tatra ālokaḥ na asti eva. yaḥ hi jīvati saḥ jīvati eva, yaḥ mrtah mrtah eva (Stcherbatsky 1969), p. 11.

Something which is necessitated to be (siddha) remains something which is necessitated to be. And something which is necessitated not to be (asiddha) remains something which is necessitated not to be. Thus, between both [concepts], there is inevitable mutual contradiction (paraspara-virodha) - in the same way as between light and darkness, between life and death. In fact, where there is light there is no darkness and where there is darkness there is no light. Who is alive, is alive and who is dead, is dead.

It is assumed that siddha is subordinated to causality (hetutā) and asiddha stays out of causality. Now, let us suppose that there exists God (Íśvara) as an actor (karta) this idea is expressed in the purāṇic texts well. From this it follows that

kim asau siddham karoti atha asiddham vā (Stcherbatsky 1969), p. 11.

He [A.S.: Íśvara] can create something which we know as what was caused (siddha) or which we know as something what is beyond causality (asiddha).

Let us consider the first possibility, namely that a deity creates something causal (siddha). But it is impossible, as "for example, we know that man exists. Creating him further cannot be an act of creation; because his existence is already established [i.e. before this alleged creation by God]" (Stcherbatsky 1969), p. 9. Now, we can 
examine the second possibility that God creates something staying outside causality (asiddha) such as "oil [crushed] out of sand, which is known to us as non-existent; wool on a tortoise, which is known to us as non-existent" and so on. However, such things are impossible - they are necessitated not to be. Hence, they cannot be created as well.

We can assume also that God "makes non-existent existent" (Stcherbatsky 1969), p. 9., i.e. He creates something that is siddha from something that is asiddha. But it is impossible, too. The point is that both concepts are mutually exclusive, see $\left(\mathrm{N}_{2}\right)$.

Thus, God cannot create (i) siddha (it exists because of causality, not because of God); (ii) asiddha (it stays out of causality and cannot exist at all even by the will of God); (iii) siddha from asiddha (both concepts are mutually exclusive and cannot be connected).

After that Nāgārjuna asks the question whether God, to be an actor (karta), should be born or unborn. Let us regard the first possibility that He can act being unborn. But it is absolutely impossible, "because He is Himself something unborn, like 'the son of a barren woman', who being unborn, cannot perform any action like the digging of the earth" (Stcherbatsky 1969), p. 9. As we see, the term 'unborn' is exemplified by something that is asiddha (necessitated not to be): 'the son of a barren woman'. In other words, if God is unborn, then it means that He is asiddha and cannot act in any way - He is outside causality. Thus, to be active, God should be born - He should be siddha Himself, i.e. to be Himself subordinated to causality.

Now, there are the next two possibilities: (i) God was born from something or someone else and (ii) God was born from Himself. Let us start from the first possibility and assume that He was born from another being. Then it contradicts to His definition as someone who has no origin (anādi). As a consequence, in this case $\mathrm{He}$ is asiddha as containing the following contradiction: 'having no beginning' and 'born from another being' at once. So, He does not exist. Now, let us consider the second possibility that God was born from Himself. Nevertheless it is impossible, too, "since one's own actions cannot relate to one's own self. The blade of a sword, howsoever sharp it may be, cannot cut itself. Even the most expert dancer, howsoever skilful he may be, cannot dance standing on his own shoulders. Besides, it is never observed that one and the same object is the produced (janya) and the producer (janaka). A person, who is the father is himself also the son - such an assertion is quite unknown in common discourse" (Stcherbatsky 1969), p. 9. As we see, according to Nāgārjuna, 'being born from Himself' is asiddha, i.e. this notion denotes something unreal, because it contradicts to the notion of causality.

Hence, if we posit the logical determinism (Nāgārjuna's claims $\left(\mathrm{N}_{1}\right)$ and $\left(\mathrm{N}_{2}\right)$ ), then purānic deities are impossible in principle, because they are asiddha. This Nāgārjuna's atheistic approach has been inherited by the Yogācārins. So, their atheism is rather explained by the intuitive application of modal logic $\mathbf{K}=$ in their reasoning, than by a religious believe to avoid the purāṇic gods. 


\section{Conclusion}

There exists the basic modal logic $\mathrm{K}$ which has two different extensions (Garson 2006): the logic $\mathrm{T}$ assuming contingency and the logic $\mathrm{K}=$ assuming logical

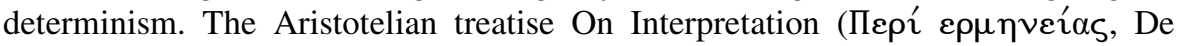
Interpretatione) has introduced some modal-logical relationships which correspond to T. In other words, Aristotle has supposed that there are contingent events A such that $\diamond \mathrm{A} \wedge \diamond \neg \mathrm{A}$ is true. The Nāgārjunian treatise Íśvara-kartṛtva-nirākṛtiḥ-viṣṇohekakartṛtva-nirākaraṇa has introduced some modal-logical relationships which correspond to $\mathrm{K}=$, namely Nāgārjuna has assumed that any event $\mathrm{A}$ is either siddha or asiddha: $\square \mathrm{A} \vee \square \neg \mathrm{A}$. His approach has been inherited by the Yogācārins who have developed, first, the doctrine of causality of all real entities (arthakriyātva), see $\left(\mathrm{Y}_{1}\right)$, and, second, the doctrine of momentariness of all real entities (kṣaṇikavāda), see $\left(\mathrm{Y}_{5}\right)$. The Nāgārjunian ideas of logical determinism can be observed also in the Stoic logical fragments. The Stoics have created, first, the doctrine of causality of all real entities (ává $\gamma \kappa \eta)$, see $\left(S_{1}\right)$, and, second, the doctrine that everything happens

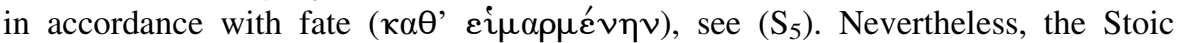
philosophy differs a lot from the Yogācāra philosophy, although both philosophies support the same logical determinism.

This research is supported by the Russian Science Foundation, Agreement No. 21-18-00366, the project entitled The Analytical History of Eternity: Temporology in Mirror of Eternalism is fulfilled at the HSE University (Moscow, Russia).

On behalf of all authors, the corresponding author states that there is no conflict of interest.

Open Access This article is licensed under a Creative Commons Attribution 4.0 International License, which permits use, sharing, adaptation, distribution and reproduction in any medium or format, as long as you give appropriate credit to the original author(s) and the source, provide a link to the Creative Commons licence, and indicate if changes were made. The images or other third party material in this article are included in the article's Creative Commons licence, unless indicated otherwise in a credit line to the material. If material is not included in the article's Creative Commons licence and your intended use is not permitted by statutory regulation or exceeds the permitted use, you will need to obtain permission directly from the copyright holder. To view a copy of this licence, visit http:// creativecommons.org/licenses/by/4.0/.

\section{References}

Beal, Samuel. Si-Yu-Ki. Buddhist Records of the Western World. In two volumes. Vol. I. London Kegan: Paul, Trench, Trübner \& co., 1884/1981.

Bhattacharyya, Gopikamohan. (1961). Studies in Nyāya-Vaiśeșika Theism. Calcutta: The Principal, Sanskrit College.

Bobzien, Susanne. (1998). Determinism and Freedom in Stoic Philosophy. Oxford: Clarendon Press.

Dharmottarapradipa (subcommentary on Dharmottara's Nyayabindutika on Dharmakīrti's Nyayabindu) Based on the ed. by Dalsukhbai Malvania. Patna: Kashiprasad Jayaswal Research Institute (Tibetan Sanskrit Works, 2), 1971.

Gautama. Nyayasutra with Vatsyayana's Nyayabhasya Based on the edition by Taranatha NyayaTarkatirtha. (Calcutta Sanskrit Series, 18 \& 19). Calcutta : Metropolitan Printing \& Publ. 1936-1944

Cowherds, The. (2011). Moonshadows: Conventional Truth in Buddhist Philosophy. Oxford: Oxford University Press. 
Descriptive Catalogue of the Naritnsan Institute Collection of Tibetan Works. Vol. I. Tokyo, 1989.

Garson, James W. (2006). Modal Logic for Philosophers. Cambridge: Cambridge University Press.

Hattori, Masaaki. (1968). Dignāga, On Perception, being the Pratyakșapariccheda of Dignāga's Pramannasamuccaya from the Sanskrit fragments and the Tibetan versions. Cambridge, Massachusetts: Harvard University Press.

Kantor, H., \& Salvini, M. (2019). Words, Concepts, and the Middle Way: Language in the Traditions of Madhyamaka Thought. Journal of Indian Philosophy, 47(4), 603-611.

Lévi, S. Mahāyānasūtrālaṃāara, Exposé de la doctrine du Grand Véhicule. Vol. I. Paris, 1907.

Mūlamadhyamakakārikās (as found in the Prasannapadā Madhyamakavṛttih by Candrakīrti). Ed. together with the Prasannapadā by L. de La Vallée Poussin, Bibliotheca Buddhica iv, St. Petersburg, 190313; reprinted with alterations by P. L. Vaidya, Madhyamakaśāstra of Nāgārjuna, Buddhist Sanskrit Texts no. 10, Darbhanga, 1960. New edition (using a fourth manuscript of the Kārikās only) by J. W. de Jong, Adyar, 1977.

Pradhan, Prahlad. (ed.). Abhidharma-koshabhāṣyam of Vasubandhu. Patna: K.P. Jayaswal Research Institute, TSWS, 1967.

Seyfort Ruegg, David. Three Studies in the History of Indian and Tibetan Madhyamaka Philosophy. Studies in Indian and Tibetan Madhyamaka thought. Part 1. Wiener Studien zur Tibetologie und Buddhismuskunde; Heft 50. Wien: Arbeitskreis für Tibetische und Buddhistische Studien, Universität Wien, 2000.

Sebastian, C. D. The Cloud of Nothingness. The Negative Way in Nagarjuna and John of the Cross. Sophia Studies in Cross-cultural Philosophy of Traditions and Cultures. Springer India, 2016.

Stcherbatsky, Th. A Buddhist Philosopher on Monotheism, [in:] Papers of Th. Stcherbatsky (Soviet Indology series, no. 2). Indian Studies: Past \& Present, 1969, pp. 1-11.

Tachikawa, Musashi. (1981). The Structure of the World in Udayana's Realism: A Study of the Lakșanāvalī and the Kirañāvalì (Studies of Classical India) (Volume 4). Dordrecht, Boston, London: D. Reidel Publishing Company.

Tillemans, T. F. (1984). Two Tibetan texts on the "neither one nor many" argument for śūnyatā. Journal of Indian Philosophy, 12(4), 357-388.

Tillemans, T. F. (1989). Formal and semantic aspects of Tibetan Buddhist debate logic. Journal of Indian Philosophy, 17(3), 265-297.

Tillemans, Tom J. F. Dharmakīrti's Pramānavārttika: an annotated translation of the fourth chapter (parārthānumāna): K.1-148. Wien: Österreichische Akademie der Wissenschaften, 2000.

Ui, H., Suzuki, M., Kanakura, Y., \& Tada Sendai, T. (Eds.). (1934). A Complete Catalogue of the Tibetan Buddhist Canons (Bkah-hgyur and Bstan-hgyur). Tokyo: Tōhoku Imperial University.

Vattanky, John. A System of Indian Logic. The Nyāya Theory of Inference. Analysis, Text, Translation and Interpretation of the anumāna section of Kārikāvalī, Muktāvalī and Dinakarī. Routledge, Curzon, 2003.

Vidyabhusana, Satis Chandra. A History of Indian Logic: Ancient, Mediaeval, and Modern Schools. Motilal Banarsidass, 1921.

Rospatt, Alexander von. The Buddhist Doctrine of Momentariness. A Survey of the Origins and Early Phase of this Doctrine up to Vasubandhu. Stuttgart: Franz Steiner Verlag, 1995.

Westerhoff, J. (2005). Nāgārjuna's Catușkoți. Journal of Indian Philosophy, 34(4), 367-395.

Westerhoff, J. (2019). Nāgārjuna and the Philosophy of Language. Journal of Indian Philosophy, 47(4), 779-793.

Publisher's Note Springer Nature remains neutral with regard to jurisdictional claims in published maps and institutional affiliations. 